\title{
M ISCELLANEA
}

\author{
Radosław Gross
}

PROBLEMY KADROWE

W PAŃSTWOWYCH MAJĄTKACH ZIEMSKICH

NA WARMII I MAZURACH (CZERWIEC 1945 - LUTY 1946)

Po drugiej wojnie światowej na terenach włączonych do państwa polskiego wykształciła się specyficzna struktura własności ziemi rolnej różniąca je od pozostałych obszarów w kraju. Forsowana przez komunistów koncepcja ustroju rolnego na tzw. Ziemiach Odzyskanych, oparta w dużej części na wielkiej państwowej własności ziemskiej, wyraźnie róźniąca te tereny od tzw. ziem dawnych ${ }^{1}$, wymagała od władz odpowiedniej polityki osiedleńczej oraz sprawnej or ganizacji i zagospodarowania majątków ziemskich, zniszczonych na tym obszarze w więksżym stopniu niż w pozostałej części kraju. Warunkiem efektywnego funkcjonowania poniemieckich folwarków, zresztą tak jak i rolnictwa indywidualnego, było szybkie skierowanie do pracy doświadczonych i odpowiednio przygotowanych kadr, które miały nimi zarządzać, a także zorganizowanie siły roboczej do prac rolnych. Od skutecznej realizacji tych zadań zależał rozwój nie tylko majątków państwowych, lecz także całego rolnictwa i wsi na Warmii i Mazurach, zważywszy, że do lutego 1946 r. powierzchnia państwowych gospodarstw stanowiła niemal 30\% ogólnej powierzchni Okręgu Mazurskiego i, według róż-

\footnotetext{
${ }^{1}$ Koncepcje dotyczące nowej struktury rolnej na terenach włączonych do Polski były opracowywane przez członków powołanej przy Biurze Studiów Osadniczo-Przesiedleńczych Rady Naukowej dla Zagadnień Ziem Odzyskanych. Opierały się one na stworzeniu średnich i dużych gospodarstwach indywidualnych (10-25 ha), m.in. poprzez rozparcelowanie wielkich majątków ziemskich. Przeciwko tym propozycjom wystąpili komuniści, którzy forsowali własną koncepcję ustroju rolnego. Opierała się ona na stworzeniu gospodarstw małych i średnich, nieprzekraczających 10 ha, oraz ogromnych domen państwowych o powierzchni powyżej 1 mln ha, zob.: R. Buławski, Problemy osadniczo-przesiedleńcze Ziem Odzyskanych, w: I Sesja Rady Naukowej dla Zagadnień Ziem Odzyskanych (30 VII - 1 VIII 1945 r.), Kraków 1945/1946, z. 1, s. 8 i n.; wystąpienie W. Wolskiego zamykające pierwszy cykl referatów, w: ibidem, s. 106 i n.; W. Styś, Zagadnienie ustroju rolnego na Ziemiach Odzyskanych, w: II Sesja Rady Naukowej dla Zagadnień Ziem Odzyskanych (16-18 XII 1945 r.), Warszawa 1946, z. 2, ss. 18-20; Archiwum Akt Nowych (dalej: AAN), Komitet Centralny Polskiej Partii Robotniczej (dalej: KC PPR), 295/I-25, k. 36, Referat E. Ochaba „Praca i zadania PPR na wsi” wygłoszony podczas I Zjazdu PPR. Szerzej na temat kształtowania ustroju rolnego na ziemiach wcielonych do Polski zob. K. Kersten, U podstaw kształtowania się nowej struktury agrarnej ziem zachodnich (1945-1947), Polska Ludowa, 1962, t. 1, ss. 37-83.
} 
nych statystyk, od 35 do 37\% gruntów ornych na tym obszarze ${ }^{2}$. Rychłe uruchomienie produkcji rolnej w przejętych poniemieckich gospodarstwach wielkopowierzchniowych mogło więc znacząco wpłynąć na poprawę aprowizacji Okręgu Mazurskiego i tym samym przełożyć się na stworzenie lepszych warunków do dalszego osadnictwa wiejskiego. Dobrze zagospodarowane folwarki przeznaczone pod parcelację stwarzały większą szansę na powodzenie akcji osadniczo-parcelacyjnej. Mogły stać się dla potencjalnych osadników bardziej atrakcyjne $^{3}$. Poza tym poprawa zaopatrzenia rynku lokalnego w żywność wzmóc mogła proces zasiedlania miast i wpłynąć na ożywienie gospodarcze Warmii i Mazur.

Skierowanie fachowej kadry i dostatecznej liczby pracowników fizycznych do przejętych w państwowy zarząd poniemieckich folwarków było więc zadaniem niezwykle ważnym dla dalszego rozwoju gospodarczego Okręgu Mazurskiego, ale jednocześnie zadaniem niełatwym. Warto więc przyjrzeć się, w jaki sposób lokalni urzędnicy administracji rolnej starali rozwiązać trudności powstające w tym obszarze gospodarczym na Warmii i Mazurach.

1. Organizacja administracji w majątkach państwowych (do lutego 1946 r.)

O̊d wiosny 1945 do lutego 1946 r. przejmowaniem z rąk sowieckich i administracją majątków ziemskich ${ }^{5}$ zajmował się Wojewódzki Urząd Ziemski

${ }^{2}$ Archiwum Państwowe w Olsztynie (dalej: APO), Komitet Wojewódzki Polskiej Partii Robotniczej (dalej: KW PPR), 1073/127, k. 71, Sprawozdanie KW PPR od 1 X 1945 do 13 IV 1946 r.; APO, KW PPR, 1074/144, k. 174, Wykaz statystyczny Okręgu Mazurskiego 1946; AAN, Zarząd Centralny Państwowych Nieruchomości Ziemskich (dalej: ZC PNZ), 429/1642, k. nlb., Zarząd Okręgowy PNZ w Łuczanach. Powierzchnia gospodarstw i użytkowanie gruntów, Tablica IIa, 19 IV 1946 r.; ibidem, k. nlb.; Zarząd Okręgowy PNZ w Olsztynie. Powierzchnia gospodarstw i użytkowanie gruntów, tab. IIa, 16 IV 1946 r. Przed wojną gospodarstwa o powierzchni ponad 100 ha zajmowały ok. 31,3\% obszaru późniejszego województwa olsztyńskiego, zob. B. Wilamowski, Zarys przemian polityczno-ekonomicznych regionu olsztyńskiego, Komunikaty Mazursko-Warmińskie (dalej: KMW), 1963, nr 3, s. 400.

${ }^{3}$ Zob.: B. Wilamowski, J. Jaworowski, Koncepcje w zakresie osadnictwa rolniczego $w$ województwie olsztyńskim w latach 1945-1948, KMW, 1967, nr 3, ss. 346-347; W. Gieszczyński, Państwowy Urząd Repatriacyjny w osadnictwie na Warmii i Mazurach (1945-1950), Olsztyn 1999, ss. 100-110.

${ }^{4}$ Dotychczasowa literatura naukowa poświęcona gospodarstwom państwowym na Warmii i Mazurach ukazała się przed 1989 r. i skupiała przede wszystkim na wynikach produkcyjnych i mechanizacji: J. Mucha, B. Wilamowski, Organizacja zarządzania oraz rozwój sił wytwórczych w gospodarstwach państwowych województwa olsztyńskiego w latach 1945-1961, KMW, 1962 , nr 1, ss. 226-270; B. Wilamowski, Zarys przemian..., ss. 375-402; idem, Wpływ warunków naturalnych na wyniki ekonomiczne na przykładzie Państwowych Gospodarstw Rolnych województwa olsztyńskiego, Olsztyn 1966, idem, Podstawy analizy i oceny działalności gospodarstw państwowych na przykładzie woj. olsztyńskiego, Warszawa 1971. Wyjątek stanowi praca Wspomnienia pracowników byłych Państwowych Gospodarstw Rolnych, opr. Z. Gładkowski, B. Pilarek, Olsztyn [2013], która jednak, z racji memuarystycznego charakteru, razi w wielu fragmentach brakiem obiektywizmu. Brak, jak dotąd, szczegółowych publikacji poświęconych początkom administracji i problematyce kadrowej w majątkach ziemskich przejętych na własność państwa.

${ }^{5}$ Sowiecki komendant wojenny w Olsztynie płk. Aleksander Szumski formalnie władzę nad Okręgiem Mazurskim przekazał pełnomocnikowi Rządu Tymczasowego Jakubowi Prawinowi 23 V 1945 r. Od przeło- 
(WUZ) w Olsztynie, na czele którego stał inż. Józef Ptaszek ${ }^{6}$. Odpowiednikiem WUZ w powiatach były powiatowe urzędy ziemskie (PUZ), na czele z komisarzami ziemskimi. Przypomnijmy, że urzędy ziemskie tworzone były na tzw. ziemiach dawnych już od jesieni 1944 r. Stanowiły one terenową strukturę administracji rolnej, ich głównym zadaniem była „opieka państwowa nad rolnictwem” i realizacja reformy rolnej zaplanowanej przez władze komunistyczne. Stąd dekret o organizacji wojewódzkich i powiatowych urzędów ziemskich przyjęto przed dekretem o reformie rolnej ${ }^{7}$.

Ekipa Wojewódzkiego Urzędu Ziemskiego przybyła do Olsztyna już 11 marca 1945 r. ${ }^{8}$ Do przełomu maja i czerwca rola komisarzy ziemskich ograniczała się do prób koordynowania żywiołowej akcji osadniczej ${ }^{9}$, gromadzenia niemieckiej statystyki rolnej, ewidencjonowania strat wyrządzonych w wyniku walk frontowych i wywożenia mienia rolniczego przez wojska sowieckie. W tych miejscach, w których zezwoliły sowieckie komendantury, urzędy ziemskie zajmowały się także ochroną majątków rolniczych i obiektów przemysłu rolniczego przed szabrem, dewastacją i zniszczeniem. Przypomnijmy, ze urzędy ziemskie zarządzały i dysponowały także gruntami włączanymi do Państwowego Funduszu Ziemi (PFZ), powołanego dekretem o reformie rolnej. Wraz z przejmowaniem do zasobu PFZ majątków ziemskich przekazywanych przez wojska sowieckie, zakres działań urzędów ziemskich rozszerzył się więc o administrowanie nieruchomościami ziemskimi.

Początkowo, ze względu na brak wewnętrznego podziału organizacyjnego Wojewódzkiego Urzędu Ziemskiego, do przełomu kwietnia i maja 1945 r. całość prac urzędu „ześrodkował” Oddział Ogólno-Organizacyjny, skupiający wszystkich pracowników WUZ, poza tymi, którzy weszli w skład Biura Prezesa. 5 maja 1945 r. został opracowany tymczasowy statut WUZ, który wyodrębnił w strukturze urzędu Wydział Funduszu Ziemi, do którego zadań należeć miało m.in.

mu maja i czerwca 1945 r. rozpoczął się proces przekazywania majątków ziemskich polskiej administracji rolnej. Przypomnijmy, że przeciągnął się on aż do czerwca 1948 r., zob.: APO, Urząd Pełnomocnika Rządu RP na Okręg Mazurski (dalej: UP), 390/65, k. 38-39, Sprawozdanie sytuacyjne za okres od 13 do 23 maja, 24 V 1945 r.; także w: Okręg Mazurski w raportach Jakuba Prawina. Wybór dokumentów 1945 r. Przygotował do druku T. Baryła, Olsztyn 1996, dok. 21, s. 65; W. Gieszczyński, Majątki ziemskie na Warmii i Mazurach pod sowiecką administracją wojskową (1945-1948), w: Między historią polityczną a społeczną, red. J. Gołota, Pułtusk-Olsztyn-Ostrołęka-Warszawa 2014, ss. 287-303.

${ }^{6}$ Od listopada 1945 r. - Edward Szymański, następnie od lutego do lipca 1946 r. - Eleonor Bialski i ponownie E. Szymański.

${ }^{7}$ Pierwszy z nich został przyjęty 15 VIII 1944 r. (Dz. U. 1944, Nr 2, poz. 4), a drugi 6 IX 1944 r. (Dz. U. 1944, Nr 4, poz. 17).

${ }^{8}$ AAN, Ministerstwo Rolnictwa i Reform Rolnych (dalej: MRiRR), 162/99, k. 8-10, Raport nr 1 prezesa WUZ w Olsztynie, 14 III $1945 \mathrm{r}$.

${ }^{9}$ Osadnictwo rolne do końca maja 1945 r. nie było skoordynowane w Okręgu Mazurskim. Niezależnie od siebie akcję osadniczą realizowały PUR i urzędy ziemskie. Od czerwca prace osiedleńcze WUZ i PUR były koordynowane przez Wydział Osiedleńczy Urzędu Pełnomocnika, szerzej zob. W. Gieszczyński, Państwowy Urząd Repatriacyjny..., Olsztyn 1999, ss. 42-43. 
administrowanie majątkami państwowymi ${ }^{10}$. Wydział ten wyłaniać się zaczął dopiero latem 1945 r., w związku z przejmowaniem od Armii Czerwonej coraz większej liczby nieruchomości ziemskich. 1 sierpnia 1945 r. rozpoczął pracę wojewódzki inspektor majątków państwowych i ośrodków wzorowych inż. Janusz Pruski ${ }^{11}$, a formalne utworzenie Wydziału Funduszu Ziemi nastąpiło, już po konferencji poczdamskiej, 1 września 1945 r. Powołano w nim Oddział Administracji Majątków Państwowych, który do lutego 1946 r., instytucjonalnie na szczeblu wojewódzkim (okręgowym), nadzorował sprawy związane z przejmowaniem i zagospodarowywaniem majątków ziemskich ${ }^{12}$. Bezpośredni nadzór nad majątkami i gospodarstwami państwowymi sprawowały powiatowe urzędy ziemskie, poprzez powiatowych inspektorów administracji majątków państwowych. Początkowo stali oni na czele, utworzonych w PUZ, inspektoratów majątków i ośrodków wzorowych i byli, jak zapisano w statucie, „organem wykonawczym takiego inspektora przy Woj. Urzędzie Ziemskim"13. Monitorowali sytuację gospodarczą i kadrową w gospodarstwach, odpowiadali za ich prawidłowe funkcjonowanie, zgłaszali problemy napotykañe na „pierwšzej linii” i w miarę możliwości pomagali je rozwiązywać ${ }^{14}$

Do końca lutego 1946 r. majątki państwowe były pogrupowane w klucze, liczace 6-7 folwarków. Na czele kluczy stali administratorzy, będący jednocześnie rządcami w jednym z majątków klucza. Na czele poszczególnych folwarków, wchodzących w skład klucza, stali rządcy. Księgowość w kluczach i majątkach prowadzili buchalterzy ${ }^{15}$. Formalnie o doborze personelu zarządzającego w poszczególnych majątkach ziemskich decydował prezes WUZ. Faktycznie wpływ na obsadę kadrową mieli także powiatowi komisarze, samodzielnie podejmujący starania o wyszukiwanie kandydatów na administratorów i rządców, których wysyłali do Olsztyna po oficjalne skierowanie do pracy od prezesa WUZ. Sprawy osobowe pracowników przyjętych w ten sposób były później prowadzone przez Oddział Personalny Wydziału Ogólnego WUZ w Olsztynie ${ }^{16}$.

W tym stanie organizacyjnym administracja majątków państwowych przetrwała do 16 lutego 1946 r. Tego dnia minister rolnictwa i reform rolnych wydał zarządzenie w sprawie przekazania przez urzędy ziemskie na tzw. Ziemiach Odzyskanych

${ }^{10}$ APO, Wojewódzki Urząd Ziemski (dalej: WUZ), 618/3, k. 154v-155, Tymczasowy statut organizacyjny WUZ w Olsztynie, 5 V 1945 r.

${ }^{11}$ Ibidem, 618/8, k. 43, Okólnik prezesa WUZ z 1 VIII 1945 r.

${ }^{12}$ Ibidem, 618/3, k. 154v-155, Tymczasowy statut organizacyjny WUZ w Olsztynie, 5 V 1945 r.

${ }^{13}$ Ibidem, 618/8, k. 18-19, Statut organizacyjny powiatowych urzędów ziemskich w województwie olsztyńskim [właśc. Okręgu Mazurskim], 16 V 1945 r.

${ }^{14}$ Ibidem, 618/3, k. 153, Tymczasowy statut organizacyjny WUZ w Olsztynie, 5 V 1945 r.

${ }^{15}$ Ibidem, 618/8, k. 43, Okólnik prezesa WUZ z 1 VIII 1945 r.

${ }^{16}$ Ibidem, 618/3, k. 153, Tymczasowy statut organizacyjny WUZ w Olsztynie, 5 V 1945 r. 
majątków o powierzchni powyżej 100 ha, nowo utworzonemu przedsiębiorstwu - Centralnemu Zarządowi Państwowych Nieruchomości Ziemskich ${ }^{17}$. Poza tym utworzono państwowe gospodarstwa wyspecjalizowane - Państwowe Zakłady Hodowli Roślin i Państwowe Zakłady Chowu Koni, którym przekazano część gruntów i inwentarza PFZ administrowanego dotychczas przez urzędy ziemskie ${ }^{18}$.

\section{Organizacja pracy w majątkach państwowych}

Wstępne zasady i instrukcje dotyczące organizacji pracy w majątkach państwowych opracowano w czerwcu 1945 r. Wówczas minister rolnictwa i reform rolnych wydał okólnik, w którym instruował wojewódzkie urzędy ziemskie o zasadach zatrudniania pracowników w państwowych majątkach rolnych. Umowy o pracę $\mathrm{W}$ rolnictwie mogły być zawierane wyłącznie w myśl zasad i przepisów określonych w układzie zbiorowym pracy z 5 czerwca 1945 r. ${ }^{19}$ Zgodnie z nim, wynagrodzenie pracowników składało się zdwóch elementów: naturaliów i pensji pieniężnej. Mieli oni również prawo do otrzymania działki, na której mogli uprawiać ziemniaki i podstawowe warzywa. Umowa obejmowała różne kategorie pracowników, różnicując ich wynagrodzenie. Najwyżej uposażeni byli pracownicy stali, stanowiący personel zarządzający w majątkach państwowych - administratorzy, rządcy i buchalterzy. Niższe uposażenia ustalono dla rzemieślników (kowali, stelmachów), a także osób dozorujących i monitujących wykonywane prace, czyli dozorców (tzw. karbowych). Podstawową siłę roboczą stanowili robotnicy rolni zatrudnieni na stałe. Wśród nich wyróżniano ordynariuszy (nazywanych fornalami) i gorzej uposażonych komorników, a także pracowników

${ }^{17}$ Ibidem, 618/12, k. 72-72v, Zarządzenie Ministra Rolnictwa i Reform Rolnych Nr FZ/1-I-2/12 z 16 II 1946 r. Analogiczne zarządzenie, dotyczące tzw. ziem dawnych, zostało wydane 11 IV 1946 r. Obszar Warmii i Mazur podzielono na dwa Okręgi PNZ: olsztyński i giżycki (wschodnio-mazurski). W lutym dyrektor ZC PNZ W. Maringe powołał pełnomocników okręgowych PNZ: w Olsztynie - inż. Władysława Czarneckiego, w Giżycku (Łuczanach) - Ludwika Bernszteina. Ich biura w marcu przeorganizowano w zarządy okręgowe PNZ.

${ }^{18}$ Od momentu przekazania PNZ majątków państwowych o powierzchni powyżej 100 ha działania administracyjne urzędów ziemskich wobec pozostałych majątków (do 100 ha) w zasadzie sprowadzały się do wydzierżawiania ich różnym instytucjom i urzędom. Majątki te pełniły rolę tzw. gospodarstw pomocniczych, służących zaspokajaniu potrzeb aprowizacyjnych pracowników tych instytucji. Odpowiednie umowy dzierżawne przygotowywano w Wydziale Funduszu Ziemi (później, po włączeniu urzędów ziemskich w struktury administracji ogólnej, w Dziale Rolnictwa i Reform Rolnych Urzędu Wojewódzkiego) i przesyłano do zatwierdzenia do MRiRR. Zob. APO, WUZ, 618/15, k. 185, Sprawozdanie Wydziału Finansów Rolnych Urzędu Wojewódzkiego Olsztyńskiego za okres od 1 II do 28 II 1947 r., 5 III 1947 r; ibidem, k. 192, Sprawozdanie Wydziału Finansów Rolnych Urzędu Wojewódzkiego Olsztyńskiego za okres od 1 III do 31 III 1947 r., 10 IV 1947 r; ibidem, k. 216, Sprawozdanie Wydziału Finansów Rolnych Urzędu Wojewódzkiego Olsztyńskiego za okres od 1 VII do 31 VII 1947 r., 7 VIII 1947 r.

${ }^{19}$ Zob. wydany w formie broszury: Układ zbiorowy pracy pomiędzy Państwowym Funduszem Ziemi a Związkiem Zawodowym Robotników i Pracowników Rolnych, Warszawa 5 czerwca 1945 r. 
wykonujących prace pomocnicze: stróży, polowych, pastuchów. Poza tym zatrudniano najniżej uposażonych robotników dniówkowych i sezonowych ${ }^{20}$.

Znaczną część wynagrodzenia pracowników zatrudnionych w majątkach ziemskich stanowiło świadczenie w naturze, tzw. ordynaria. Umowa zbiorowa z czerwca 1945 r. ustalała ordynarię dla personelu, dozorców i ordynariuszy w wysokości 16 q zboża rocznie, którą powiększano o 10\% na opłatę za przemiał. Ponadto rzemieślnicy otrzymywali dodatkowo 2 q zboża, jako ekwiwalent za zużycie narzędzi. Pracownikom tym przysługiwały także działki o powierzchni 60 a na uprawę ziemniaków i tzw. ogrodowiznę. Wynagrodzenie w gotówce wspomnianych pracowników ustalono, w zależności od funkcji i kwalifikacji, na poziomie od 100 do $300 \mathrm{zł}$ miesięcznie ${ }^{21}$.

Zdecydowanie gorzej uposażoną grupą byli komornicy, którzy otrzymywali połowę ordynarii, 30 a ziemi pod ziemniaki i ogrodowiznę oraz wynagrodzenie w gotówce za dzień pracy - 4 zł. Z kolei robotników dniówkowych pod względem otrzymywanego wynagrodzenia podzielono na trzy kategorie. Otrzymywali oni za dzień pracy $2 \mathrm{~kg}$ żyta, 4-8kg ziemniaków, 0,5-1 kg pszenicyi jęčzmienia (II i III kat.) oraz w gotówce: latem 6, 8 i 10 zł, a zimą 4, 5, i 7 zł. Robotnicy sezonowi otrzymywali wynagrodzenie tej samej wysokości co robotnicy dniówkowi, przy czym dodatkowo codziennie przysługiwało im darmowe wyżywienie ${ }^{22}$.

Wspomniana umowa zbiorowa przewidywała utworzenie w majątkach państwowych „przedstawicielstwa pracowniczego" - komitetów folwarcznych, które stanowić miały rodzaj swoistych rad zakładowych, formalnie reprezentujacych interesy zawodowe pracowników danego gospodarstwa rolnego, a w rzeczywistości czuwających nad „wzmocnieniem i ulepszeniem produkcji - - w myśl ogólnych wytycznych polityki gospodarczej państwa"23. Tak naprawdę rola komitetów folwarcznych, które z czasem zaczęły działać w strukturach Związku Zawodowego Robotników i Pracowników Rolnych (ZZRiPR), sprowadzać się więc miała przede wszystkim do mobilizowania załóg do realizacji owych „wytycznych”24.

W grudniu 1945 r. minister rolnictwa i reform rolnych, wzorując się na normach przedwojennych, odgórnie ustalił liczbowe limity pracowników zatrudnianych w majątkach państwowych, które uzależniono od ich powierzch-

${ }^{20}$ APO, WUZ, 618/12, k. 6, Okólnik Ministra Rolnictwa i Reform Rolnych, czerwiec 1945 r.

${ }^{21}$ Układ zbiorowy pracy..., Dział VII, $\$ 48-50$.

${ }^{22}$ Ibidem, Dział X, $\$ 63$

${ }^{23}$ APO, WUZ, 618/12, k. 6, Okólnik Ministra Rolnictwa i Reform Rolnych, czerwiec 1945 r.

${ }^{24} \mathrm{Z}$ materiałów archiwalnych wynika, że na Warmii i Mazurach na poziomie wojewódzkim Zarząd Okręgowy ZZRiPR bardziej ożywioną działalność rozpoczął dopiero od stycznia 1948 r., zob. APO, KW PPR, 1073/159, k. 79, Sprawozdanie z działalności Związku Zawodowego Robotników i Pracowników Rolnych. Zarząd Okręgowy w Olsztynie [wrzesień 1948]. 
ni. W folwarkach najmniejszych, do 100 ha, ustanowiono etaty rządcy oraz magazyniera lub pomocnika gospodarczego. W majątkach o powierzchni od 100 do 200 ha utworzono etaty administratora i buchaltera, pełniącego jednocześnie obowiązki magazyniera, lub w jego miejsce dwa stanowiska: praktykanta i magazyniera. W majątkach o powierzchni do 300 ha, poza administratorem i buchalterem, utworzono stanowisko magazyniera lub w jego miejsce praktykanta. W folwarkach o największych powierzchniach, przekraczających 300 ha, obok administratora, buchaltera i magazyniera, utworzono etat praktykanta.

Poza personelem zarządzającym ustalono także średnią liczbę robotników rolnych (fornali), przypadającą na powierzchnię gruntów ornych. Przyjęta norma wynosiła: 1 robotnik rolny na 16 ha ziemi ornej. $W$ okresach pilnych robót fornal miał zapewnić tzw. posyłki, czyli dostarczyć folwarkom dodatkową siłę roboczą, którą najczęściej stanowiła jego rodzina i najbliżsi. Obok personetu administracyjnego i robotników rolnych ustalono także limity tzw. robotników-pomocników (na 100 ha po jednym: stróżu, polowym i pastuchu) zwiększając ich liczbę wraz ze wzrostem powierzchni majątków ${ }^{25}$.

Analiza zasad zarządzania majątkami ziemskimi na Warmii i Mazurach w okresie od czerwca 1945 do lutego 1946 r. pozwala wyciagnać wniosek, że początkowo organizacja pracy była w nich odwzorowywana na podstawie funkcjonowania przedwojennych folwarków w Polsce. Przejęto przedwojenne normy dotyczące liczby zatrudnianych robotników rolnych oraz tę samą terminologię dotyczącą poszczególnych kategorii pracowników, którym przypisano podobne funkcje i zadania. Przejęcie przedwojennego nazewnictwa spowodowało, że robotników rolnych (ordynariuszy, karbowych, fornali, komorników) nazywano „służbą”. Terminologię tę stosowało w oficjalnych dokumentach Ministerstwo Rolnictwa i Reform Rolnych (MRiRR), a za nim terenowe urzędy ziemskie.

\section{Problemy werbunkowe}

\subsection{Kadra kierownicza w majątkach ziemskich}

Wspomniane wyżej ustalenia dotyczące uposażeń i norm ilościowych pracowników zatrudnianych w majątkach państwowych były niezwykle trudne do osiągnięcia na Warmii i Mazurach - obszarze wyludnionym i wyniszczonym gospodarczo przez grabieżczą działalność wojsk sowieckich i pozornych „osadników”, szczególnie z północnego Mazowsza i Podlasia. 
Największy wpływ na funkcjonowanie majątków państwowych miała kadra zatrudniona do bezpośredniego zarządzania i pracy, czyli personel administracyjny w folwarkach i robotnicy. Jak już wspomniano, do końca lutego 1946 r. w skład personelu zarządzającego wchodzili administratorzy, rządcy i buchalterzy. Jeszcze przed formalnym przekazaniem władzy polskiej administracji przez wojska sowieckie, powiatowe urzędy ziemskie pośpiesznie poszukiwały osób na te stanowiska do „zabezpieczenia przed wywózką przez wojsko [sowieckie] narzędzi i maszyn rolniczych" 26 . Tak więc w pierwszych dniach po zakończeniu wojny rola administratorów sprowadzała się do pełnienia funkcji stróżów i dozorców, gdyż amatorów cudzej własności, zarówno wśród Sowietów, jak i części ludności polskiej, nie brakowało ${ }^{27}$.

Problem związany z werbunkiem kandydatów na stanowiska administratorów majątków państwowych zaczął narastać od czerwca 1945 r., gdy wojska sowieckie stopniowo zaczęły zwalniać poniemieckie folwarki. Dodajmy w tym miejscu, że początkowo przekazywano majątki nieliczne, zdewastowane, w znacznym stopniu zniszczone, niezagospodarowane i pozbawione inwentarza. Pozostałe, na ogół obsiane, będące w lepszym stanie gospodarczym, sowiecka armia pozostawiła do swej dyspozycji do jesieni, z zamiarem zebrania z nich plonów. Zbyt mała liczba chętnych do objęcia funkcji administratorów skłoniła WUZ w Olsztynie do wystosowania pism do MRiRR, a także do olsztyńskiego oddziału PUR, z prośbą o włączenie się w akcję werbunkową i kierowanie do urzędów ziemskich osób zainteresowanych pracą. Liczono przede wszystkim, że odpowiednio przygotowani kandydaci mogą znaleźć się wśród przesiedleńców z Kresów Wschodnich przybywających na Warmię i Mazury.

Mimo prowadzenia akcji werbunkowej i prób jej rozszerzenia, nie zaspokajano rosnących potrzeb kadrowych majątków państwowych. Zgodnie ze wspomnianymi wyżej formalnościami, kandydaci do pracy w administracji majątków musieli uzyskać skierowanie z WUZ. Z kolejnych doniesień Wydziału Funduszu Ziemi dowiadujemy się jednak, że większość tych, którzy uzyskali skierowanie, ostatecznie pracy nie podejmowało. Kandydaci, po zapoznaniu się na miejscu z warunkami pracy, wysokością proponowanego wynagrodzenia oraz warunkami bytowymi, rezygnowali. Jak informowano MRiRR, zgłaszający się „po obejrzeniu warunków na miejscu wyjeżdżają i nie wracają"28. W ciągu dwudziestu dni na

${ }^{26}$ APO, WUZ, 618/13, k 45, Sprawozdanie z działalności wojewódzkiego i powiatowych urzędów ziemskich za miesiąc maj $1945 \mathrm{r}$.

${ }^{27}$ Archiwum Instytutu Pamięci Narodowej Oddział w Białymstoku (dalej: AIPN Bi), 084/1, k. 60, Sprawozdanie miesięczne szefa WUBP w Olsztynie za okres 1 X - 31 X 1945 r.

${ }^{28}$ APO, WUZ, 618/4, k. 170, Sprawozdanie nr 13 z działalności Woj. Urzędu Ziemskiego w Olsztynie i powiatowych urzędów ziemskich oraz sytuacyjne za czas od 25 IX do 31 X 1945 r., 19 XI 1945 r. 
przełomie października i listopada 1945 r. skierowano do powiatów aż 60 administratorów, $\mathrm{z}$ których jedynie 5 podjęło pracę ${ }^{29}$. W całym listopadzie WUZ skierował „na powiaty 128 kandydatów na administratorów majątków państwowych, rządców, karbowych, pomocników gospodarczych, buchalterów i gorzelanych. Formalnie przyjęto 31 pracowników”30. Deficyt kadry zarządzającej w majątkach był więc duży. Przykładowo, w powiecie morąskim do końca października 1945 r. zdołano obsadzić administratorów zaledwie w kilku majątkach, zaś w powiecie nidzickim w 16 spośród 51 gospodarstw państwowych ${ }^{31}$.

Ilustracją problemów werbunkowych niech będą kolejne pisma komisarza ziemskiego z Bartoszyc Stefana Grabanowskiego, kierowane do prezesa WUZ. W związku z brakiem efektów własnych zabiegów o zapewnienie obsady kierowniczej w folwarkach przejmowanych od Sowietów, 3 września Grabanowski zwracał się z prośbą o niezwłoczne przysłanie „pięciu administratorów, a w najgorszym razie karbowych, gdyż Armia Czerwona opuszcza majątki i nie ma kto przypilnować tego, co jeszcze nie zostało całkowicie zniszczone”. Po tygodniu, w kolejnym piśmie, dodał, że powiat bartoszycki „znany jest wszystkim z kradzieży, napadów, bicia i dokonywania rabunków w biały dzień”. Miał jednak nadzieję, że prezes WUZ pomoże znaleźć młodych ,ideowych, choćby z niższym wykształceniem rolniczym, którzy by dopilnowali tego, co jeszcze całkowicie nie zostało zniszczone”. Dziesięć dni później, po tym, jak jego wcześniejsze prośby nie przyniosły skutku, w kolejnym liście napisał: „Że do Bartoszyc nikt nie chce jechać - to wiadomo, ale jeżeli jeden głupiec, stary Grabanowski się znalazł, to może jeszcze i młodzi podobni się znajdą?”32.

Bardziej energiczni komisarze ziemscy, nie czekając na wyniki akcji werbunkowej Wojewódzkiego Urzędu Ziemskiego, sami aktywnie włączali się w proces rekrutacji. Komisarz ziemski PUZ w Ostródzie Jerzy Binzer tak opisał własne działania w tym zakresie: „Opierałem się na kandydatach przysyłanych przez WUZ, jednakże sam sprawdzałem ich kwalifikacje i odpowiednio do tego przydzielałem prace. Sam jeździłem, wysyłałem swoich delegatów do centr.[alnej] Polski w celu werbowania kandydatów, których następnie kierowałem do WUZ w celu załatwienia formalności”33. Wskazywany innym komisarzom powiato-

\footnotetext{
${ }^{29}$ Ibidem, 618/14, k. 29, Sprawozdanie Wydziału Funduszu Ziemi za okres od 25 X do 15 XI 1945 r., 15 XI 1945 r.

${ }^{30}$ Ibidem, 618/4, k. 183, Sprawozdanie nr 14 z działalności Wojewódzkiego Urzędu Ziemskiego w Olsztynie i powiatowych urzędów ziemskich oraz sytuacyjne za czas od 1 XI do 30 XI 1945 r., 29 XII 1945 r.

${ }^{31}$ Ibidem, k. 170v, Sprawozdanie nr 13 z działalności Woj. Urzędu Ziemskiego w Olsztynie i powiatowych urzędów ziemskich oraz sytuacyjne za czas od 25 IX do 31 X 1945 r., 19 XI 1945 r.

${ }^{32}$ Ibidem, 618/34, k. 110, Pismo komisarza PUZ w Bartoszycach Stefana Grabanowskiego do WUZ w Olsztynie, 3 IX 1945 r.; ibidem, k. 111, Pismo komisarza PUZ w Bartoszycach do WUZ w Olsztynie, 10 IX 1945 r.; ibidem, k. 167, Pismo komisarza PUZ w Bartoszycach do WUZ w Olsztynie, 20 IX 1945 r.

${ }^{33}$ Ibidem, 618/18, k. 48v, Protokół z I Zjazdu kierowników PUZ województwa olsztyńskiego [właśc. Okręgu Mazurskiego] odbytego w dniach 29 i 30 X 1945 r. w Olsztynie.
} 
wym, jako przykład do naśladowania, Binzer miał jednak dość ułatwione zadanie. Powiat ostródzki, w porównaniu z innymi, szczególnie północnymi, był stosunkowo szybko zaludniany, stąd możliwości zagospodarowania i obsadzenia majątków ziemskich były większe.

Do końca interesującego nas okresu, gdy administracją majątków państwowych zajmowały się urzędy ziemskie, nie udało się kierownikom PUZ rozwiązać problemu niedoboru kadr zarządzających w przejętych poniemieckich folwarkach. Ze statystyki sporządzonej w marcu $1946 \mathrm{r}$. przez zarządy okręgowe PNZ w Olsztynie i Giżycku, dotyczącej majątków przejmowanych od urzędów ziemskich, wynika, że w 1196 otrzymanych gospodarstwach zatrudnionych było zaledwie 347 administratorów, rządców i pomocników administratorów. Urzędy ziemskie zdołały więc obsadzić najwyżej $29 \%$ gospodarstw ${ }^{34}$.

Zastanówmy się w tym miejscu, dlaczego akcja werbunkowa nie przynosiła oczekiwanych rezultatów? Wydaje się, że zdecydowało kilka przyczyn, wśród których, poza wspomnianym wyżej wyludnieniem Okręgu Mazurskiego, na czoło wysunęly się zły stan bezpieczeństwa, szczególnie poza miastami, oraz fatalne warunki bytowe. Stała obawa o posiadane mienie, a przede wszystkim życie i zdrowie, skutecznie odstraszała pracowników i potencjalnych kandydatów do pracy w majątkach państwowych. Zagrożenie szło z kilku kierunków. Najpoważniejsze stanowiły oddziały sowieckie stacjonujące w Okręgu Mazurskim, a także sowieccy maruderzy. Groźne były również zorganizowane grupy polskich szabrowników, zapuszczające się na Warmię i Mazury z zamiarem ograbiania miast, wsi oraz majątków ziemskich z wszelkich dóbr stanowiących jakąkolwiek wartość, poczynając od narzędzi i maszyn rolniczych, poprzez zachowane gdzieniegdzie płody rolne, a kończąc na przedmiotach codziennego użytku, stanowiących wyposażenie domów. Dodajmy, że względy bezpieczeństwa i braki kadrowe początkowo skłaniały pracowników PUZ do zagospodarowywania w pierwszej kolejności majątków leżących w pobliżu miast, o czym w sprawozdaniu do MBP donosił w listopadzie 1945 r. szef WUBP Henryk Palka ${ }^{35}$.

W wielu meldunkach i relacjach wytworzonych przez pracowników urzędów ziemskich znajdujemy ogromną ilość informacji na temat złego stanu bezpieczeństwa. W kolejnych sprawozdaniach przesyłanych do MRiRR prezes WUZ alarmował, że zagrożone jest funkcjonowanie majątków państwowych,

${ }^{34}$ Obliczenia własne na podst.: AAN, ZC PNZ, 429/1642, k. nlb., Statystyka większych gospodarstw rolnych na podstawie danych z przejęcia gospodarstw przez ZO PNZ w Łuczanach, Tablica I; ibidem, k. nlb., Statystyka większych gospodarstw rolnych na podstawie danych z przejęcia gospodarstw przez ZO PNZ w Olsztynie, Tablica I; ibidem, k. nlb., Zatrudnienie w gospodarstwach objętych zespołami ZO PNZ w Łuczanach, Tablica IVa; ibidem, k. nlb., Zatrudnienie w gospodarstwach objętych zespołami ZO PNZ w Olsztynie, Tablica IV.

${ }^{35}$ AIPN Bi, 084/1, k. 61, Sprawozdanie miesięczne szefa WUBP w Olsztynie za okres 1 X - 31 X 1945 r. 
w których dokonywane były „stałe kradzieże inwentarza żywego przez jednostki Armii Czerwonej i maruderów”. Wojska sowieckie i polskie bezprawnie dokonywały omłotu zbóż, a także wywoziły sprzęt rolniczy. W związku z tym nastąpił „odpływ zarówno pracowników majątków państwowych, jak i osadników”36. Samowola wojsk sowieckich, a także, podkreślmy, wojsk polskich ${ }^{37}$, w efekcie prowadziła więc nie tylko do dalszego ogołacania majątków państwowych, lecz także porzucania stanowisk pracy przez osoby, które były w nich zatrudnione ${ }^{38}$. Rabunki nie omijały rządców i administratorów. Niektórym żołnierze sowieccy rabowali mienie prywatne, „przyłożywszy rewolwer do skroni”39. Nie byli im w stanie zapobiec funkcjonariusze MO i UB. Jak informował prezes WUZ w Olsztynie, w jednym $\mathrm{z}$ majątków państwowych $\mathrm{w}$ powiecie reszelskim (biskupieckim) „mimo interwencji MO i funkcjonariuszy UB - żołnierze radzieccy zabrali siłą 32 wozy koniczyny, pozbawiając przez to majątek paszy dla inwentarza. Odnotowano również 2 wypadki zabrania siłą koni majątkowych" ${ }^{40}$.

Jednak wojska sowieckie, jak już wspomniano, nie były jedynym źródłem zagrożenia majątków państwowych i ich pracowników. Równie silną grozę wśród osadników i kadr państwowych gospodarstw wzbudzały uzbrojone grupy szabrowników, przede wszystkim w powiatach położonych wzdłuz przedwojennej granicy polsko-niemieckiej. W grudniowym sprawozdaniu prezesa WUZ, czytamy: „Grasują po wsiach uzbrojone bandy, które szczególnie działają w dawnym pasie przygranicznym. - - Nawet w najbliższym sąsiedztwie Szczytna potrafią bandyci rabować inwentarz. W nocy z 13 na 14 listopada [1945 r.] grupa uzbrojonych bandytów napadła na państwowy folwark Waldhof, położony w odległości $1 \mathrm{~km}$ od Szczytna i sterroryzowawszy służbę, zrabowała 2 konie i 3 krowy", co wyraźnie pogorszyło nastroje pracowników ${ }^{41}$.

Dość ciekawą relację, dotyczącą grabieży majątków państwowych, przedstawił komisarz ziemski PUZ w Węgorzewie. Informował o tym, że chłopi z su-

\footnotetext{
${ }^{36}$ APO, WUZ, 618/4, k. 151-152, Sprawozdanie nr 12 z działalności Woj. Urzędu Ziemskiego w Olsztynie i powiatowych urzędów ziemskich oraz sytuacyjne za czas od 1 do 25 IX 1945 r., 27 IX 1945 r.

${ }^{37} \mathrm{O}$ samowoli i rabunkach w majątkach państwowych dokonywanych przez jednostki wchodzące w skład 14. i 15. Dywizji Piechoty stacjonujących w Okręgu Mazurskim informowali komisarze ziemscy. Z powiatu morąskiego donoszono: „Dowódcy jednostek wojska polskiego dopuszczają się samowoli, zabierając przymusowo konie, omłacając zboże na cele niezwiązane z rolnictwem”. Komisarz ziemski z Ostródy alarmował: „niektórzy dowódcy oddziałów WP zabierają omłócone zboże do swojej dyspozycji”, zob. ibidem, k. 154-155, Sprawozdanie nr 12 z działalności Woj. Urzędu Ziemskiego w Olsztynie i powiatowych urzędów ziemskich oraz sytuacyjne za czas od 1 do 25 IX 1945 r., 27 IX 1945 r.

${ }^{38}$ Ibidem, 618/14, k. 26v, Sprawozdanie Wydziału Funduszu Ziemi za okres sprawozdawczy od 1 do 15 IX 1945 r., 19 IX 1945 r.

${ }^{39}$ Ibidem, 618/4, k. 186-187, Sprawozdanie nr 14 z działalności Wojewódzkiego Urzędu Ziemskiego w Olsztynie i powiatowych urzędów ziemskich oraz sytuacyjne za czas od 1 XI do 30 XI 1945 r., 29 XII 1945 r.

${ }^{40}$ Ibidem, k. 186, Sprawozdanie nr 14 z działalności Wojewódzkiego Urzędu Ziemskiego w Olsztynie i powiatowych urzędów ziemskich oraz sytuacyjne za czas od 1 XI do 30 XI 1945 r., 29 XII 1945 r.

${ }^{41}$ Ibidem, k. 187.
} 
walskiego przybywali na teren Okręgu Mazurskiego i rabowali majątki państwowe, wchodząc w konfidencję z sowieckimi maruderami, którzy stanowili ich swoistą „obstawę”. Pracownicy majątków próbujący bronić własnego dobytku i państwowego mienia „pod lufami automatów musieli ustąpić", a szabrownicy naładowawszy wozy zrabowanymi dobrami „odjechali spokojnie”42. Warto w tym miejscu podkreślić, że odnotowywano także przypadki, w których szabrownicy własne kradzieże chcieli zrzucić na konto wojsk sowieckich. Komisarz PUZ w Nidzicy, pisząc o kradzieżach i rabunkach Armii Czerwonej, nadmienił: „niejednokrotnie i nasi mieszkańcy, pod płaszczem wojsk sowieckich, dają upust złym skłonnościom"ł3.

Trudno się dziwić, że wobec przytoczonych wyżej przykładów zuchwałych napadów i grabieży, świadczących o poczuciu bezkarności szabrowników, komisarze ziemscy w Okręgu Mazurskim zgłaszali zwierzchnikom pilną potrzebę uzbrojenia pracowników administracji majątków państwowych, którzy dzięki temu "własnymi siłami mogliby zapobiec rozgrabianiu mienia państwowego" ${ }^{44}$. Dodajmy na marginesie, że problem niedostatečznego stanu bežpieczeństwa dotykał nie tylko kadrę poniemieckich folwarków, lecz także pracowników w urzędach ziemskich, pracujących w oddziałach tub referatach majątków państwowych, którzy podczas delegacji służbowych niejednokrotnie stawali się obiektem napaści. Również oni zgłaszali potrzebę przydzielenia pracownikom wysyłanym w teren broni palnej, przynajmniej krótkiej ${ }^{45}$. Nic więc dziwnego, że inspektorzy obwodowi majątków państwowych, których specyfika pracy zmuszała do wielokrotnych wyjazdów w teren, narażeni na niebezpieczeństwo, często rezygnowali. Rotacja na tych stanowiskach była duża. W zasadzie w każdym kolejnym sprawozdaniu Wydziału Funduszu Ziemi informowano o odejściu osób zajmujących to stanowisko i przyjęciu nowych na ich miejsce ${ }^{46}$.

Poza brakiem bezpieczeństwa, niezwykle istotnym czynnikiem przekładającym się na niski stan zatrudnienia w majątkach państwowych były niewysokie wynagrodzenia i ich nieregularne wypłaty oraz fatalne warunki bytowe. Jak już wyżej wspomniano, uposażenia pracowników składały się z dwóch elementów: naturaliów i gotówki. Jednak ogołocenie majątków ziemskich z inwentarza 29 X 1945 r

${ }^{42}$ Ibidem, 618/18, k. 24v, Sprawozdanie powiatowego komisarza ziemskiego w Węgoborku za czas 30 IX

${ }^{43}$ Ibidem, k. 44, Sprawozdanie PUZ w Niborku za czas 1 IV do 25 X 1945 r.

${ }^{44}$ Ibidem, 618/34, k. 31, Pismo komisarza ziemskiego PUZ w Lidzbarku Warmińskim do WUZ, 10 XII 1945 r.

${ }^{45}$ Ibidem, 618/15, k. 5, Raport inspektora obwodowego majątków państwowych Władysława Lubczańskiego, 10 IX 1945 r.

${ }^{46}$ Ibidem, 618/14, k. 28, Sprawozdanie Wydziału Funduszu Ziemi za okres sprawozdawczy od 12 do 25 X 1945, 31 X 1945 r.; ibidem, k. 29; Sprawozdanie Wydziału Funduszu Ziemi za okres od 25 do 15 XI 1945 r., 15 XI 1945 r.; ibidem, Sprawozdanie Wydziału Funduszu Ziemi za okres od 15 XI do 1 XII 1945 r., 3 XII 1945 r., k. 30. 
żywego, płodów rolnych i sprzętu rolniczego przez wojska sowieckie, dokonane jeszcze przed ich przekazaniem polskiej administracji, a także nieustanne późniejsze rabunki i grabieże, prowadziły do gospodarczego upadku wielu z nich. Zagospodarowanie majątków w takim stanie było niezwykle trudne. Tym bardziej że zgodnie z założeniem systemu wynagradzania ich pracowników, znaczna część uposażeń miała pochodzić z produkcji własnej w formie wspomnianych naturaliów, czyli ordynarii. Stąd w pierwszym okresie potrzebna była pomoc z zewnątrz w postaci zaopatrzenia, nie tylko w siłę pociągową, sprzęt rolniczy i płody rolne przeznaczone pod zasiew, lecz także środki żywnościowe, które mogłyby, choć częściowo, zrekompensować brak możliwości wydawania naturaliów. Jednak stan aprowizacji, nie tylko majątków państwowych, lecz całego Okręgu Mazurskiego w pierwszych powojennych miesiącach był bardzo zły. Do tego wspomniany brak inwentarza żywego, szczególnie koni, jako podstawowej siły pociągowej, niezbędnej do ponownego zagospodarowania majątków, był barierą, która skutecznie zniechęcała potencjalnych kandydatów do podejmowania pracy w państwowych gospodarstwach, a tych, których udało się zwerbować, do jej kontynuowania $\frac{47}{7}$.

Jeszcze innym czynnikiem pogłębiającym trudności w realizacji wypłat naturaliów w majątkach państwowych był obowiązek przekazywania niewielkich zapasów płodów rolnych, znajdujących się w przejętych majątkach, Wydziałowi Aprowizacyjnemu w Urzędzie Pełnomocnika i referatom aprowizacyjnym w starostwach. Wypłata wynagrodzeń w naturze w majątkach państwowych była więc ogromnym problemem. Przekładało się to na nastroje pracowników. Z powiatów donoszono, że naturalia, które przysługiwały administratorom, zgodnie z układem zbiorowym z 5 czerwca 1945 r., istniały tylko „w teorii”. W majątkach niezniszczonych, dobrze urządzonych, warunki określone w powyższym układzie mogły gwarantować utrzymanie kadry, lecz, w spustoszonych, pozbawionych inwentarza i niezagospodarowanych, były „tylko piękną obietnicą" ${ }^{48}$. Dramatyczny stan zaopatrzenia pracowników majątków w żywność skłaniał wielu komisarzy ziemskich do dość odważnych decyzji o przekazaniu części ziarna siewnego administratorom i robotnikom do konsumpcji. Tłumaczyli zwierzchnikom z olsztyńskiego WUZ, że był to jedyny sposób na zapewnienie obsadzie państwowych gospodarstw środków niezbędnych do przetrwania ${ }^{49}$.

Pracownicy Wydziału Funduszu Ziemi w WUZ w Olsztynie otwarcie wiązali sprawę niskich uposażeń personelu z niewystarczającym stanem zatrudnie-

${ }^{47}$ APO, KW PPR, 1073/127, k. 72, Sprawozdanie Wydziału Rolnego KW PPR za okres 1 X 1945 - 13 IV 1946 r.

${ }^{48}$ APO, WUZ, 618/18, k. 23v, Sprawozdanie powiatowego komisarza ziemskiego w Węgoborku za czas 30 IX 29 X 1945 r.

${ }^{49}$ Ibidem, k. 33, Sprawozdanie kierownika PUZ w Olsztynie, 29 X 1945 r. 
nia w majątkach państwowych. Brak naturaliów, przy niewysokich pensjach pieniężnych (200-300 zł), prowadził do rezygnacji pracowników lub ich „nadużyć i kombinacji”"50. Już w sierpniu 1945 r. z Okręgu Mazurskiego do MRiRR udała się delegacja pracowników ziemskich, na czele z inspektorem majątków państwowych WUZ, z wnioskiem o wypłacanie administratorom specjalnych diet w wysokości 60-80 zł dziennie i zapewnienie zatrudnionym w folwarkach opieki lekarskiej. Wniosek ten nie został jednak pozytywnie rozpatrzony ${ }^{51}$.

Problemy z zapewnieniem odpowiedniej obsady w gospodarstwach państwowych wzrosły jeszcze bardziej po żniwach 1945 r., gdy wojska sowieckie zaczęly zwalniać kolejne majątki ziemskie, pozbawione wszelkich dóbr, nasion i innych ziemiopłodów, które mogłyby posłużyć do wyżywienia personelu i robotników ${ }^{52}$. Do końca października 1945 r., spośród 1269 majątków ziemskich zajmowanych przez wojska sowieckie, powiatowe urzędy ziemskie przejęly 554 folwarki, z których zdołano zagospodarować około 25\%. Jak relacjonował szef WUBP w Olsztynie: „Stan majątków pod względem inwentarza martwego i żywego jest opłakany, gdyż wojska sowieckie wszystko wywożą, a pozostawioną część tak niszczą, że są nie do użytku"s3 Z Z jednej strony fakt przekazywania majątków cieszył polską administrację, $z$ drugiej jednak, zdawano sobie sprawę z problemu, jakim będzie ich zagospodarowanie i zapewnienie środków na wynagrodzenia angażowanemu personelowi oraz robotnikom ${ }^{54}$.

Wspomniane niskie wynagrodzenia i problemy z realizacją wypłat naturaliów nie zachęcały do podejmowania pracy w majątkach ziemskich, a zatrudnionym nie dawały szans na poprawę fatalnych warunków bytowych. Ponury obraz ich trudnej sytuacji kreślił w swym sprawozdaniu komisarz ziemski z Węgorzewa: „Położenie administratorów jest bardzo ciężkie. Nie mają oni żadnych środków egzystencji. Na pustym majątku, prócz chleba, nie mają po prostu co jeść, a i kupić za co nie mają - -. Los naszych administratorów jest opłakany i dziwić się nie można, że nie ma na te posady chętnych, a ci co spróbują - uciekają"55.

Komisarze ziemscy z pozostałych powiatów donosili o analogicznych warunkach pracy $\mathrm{w}$ folwarkach przejętych od wojsk sowieckich. Stan aprowizacji był w nich tak zły, że przebywający 23 sierpnia 1945 r. w Olsztynie Stanisław Mi-

${ }^{50}$ Ibidem, 618/14, k. 26v, Sprawozdanie Wydziału Funduszu Ziemi za okres sprawozdawczy od 1 do 15 IX 1945 r., 19 IX 1945 r.

${ }^{51}$ AAN, MRiRR, 162/99, k. 6, Protokół konferencji wicepremiera S. Mikołajczyka z prezesem i naczelnikami WUZ w Olsztynie, 23 VIII $1945 \mathrm{r}$.

${ }^{52}$ AIPN Bi, 084/1, k. 25-26, Sprawozdanie dekadowe Sekcji V WUBP w Olsztynie 19-29 IX 1945 r.

${ }^{53}$ Ibidem, k. 61, Sprawozdanie miesięczne szefa WUBP w Olsztynie za okres 1 X - 31 X 1945 r.

${ }^{54}$ APO, WUZ, 618/18, k. 34, Sprawozdanie kierownika PUZ w Olsztynie, 29 X 1945 r.

${ }^{55}$ Ibidem, k. 23v, Sprawozdanie powiatowego komisarza ziemskiego w Węgoborku za czas 30 IX 29 X 1945 r. 
kołajczyk ${ }^{56}$ polecił, aby w pierwszym rzędzie wspomniane wyżej niewielkie zapasy żywności znajdujące się w przejętych majątkach przeznaczać „na zabezpieczenie robotników folwarcznych i na pokrycie własnych potrzeb majątkowych, a dopiero resztę przekazywać wydziałom aprowizacyjnym z wystawieniem rachunków na rzecz Funduszu Ziemi” ${ }^{57}$. Podczas pierwszego zjazdu komisarzy ziemskich w październiku 1945 r., na pytanie dyrektora Departamentu Przebudowy Ustroju Rolnego w MRiRR Adama Szczerby, dlaczego jeszcze nie obsadzono dużej części majątków państwowych w powiecie lidzbarskim, tamtejszy komisarz PUZ odpowiedział: „Majątków nie obsadzono z braku ludzi, którzy do pustych i ograbionych majątków nie chcą przychodzić. W majątkach jest pustkowie, nie ma inwentarza, narzędzi, budynki [pozostają] bez opieki, żaden człowiek w tych warunkach, bez odpowiedniego zaopatrzenia, nie wytrzymuje, robotników nie ma, bo umarliby z głodu" 58 . Podobne uwagi zgłaszali inni powiatowi komisarze ziemscy.

Powyższe polecenie Mikołajczyka, aby w pierwszej kolejności płody rolne w majątkach przeznaczać na zaopatrzenie pracowników i zabezpieczenie innych potrzeb folwarków, wychodziło naprzeciw oczekiwaniom administratorów, którzy zaczęli je stosować. Jednak takie postępowanie było kwestionowane przez działaczy PPR. Instruktor KC Józef Walnkiewicz w relacji z podróży służbowej do Okręgu Mazurskiego ostro krytykował komisarzy ziemskich i administratorów za ukrywanie w majątkach zboża, którego nie chcieli przekazać „Społem”. Ich tłumaczenia o potrzebie wyżywienia pracowników i inwentarza nie przekonywały instruktora $\mathrm{KC}^{59}$.

\footnotetext{
${ }^{56}$ Stanisław Mikołajczyk, jako wicepremier oraz minister rolnictwa i reform rolnych przybył do Olsztyna 23 VIII 1945 r., a więc dzień po formalnym utworzeniu Polskiego Stronnictwa Ludowego. Był zatem jednocześnie wiceprezesem (prezesem został W. Witos) drugiej, obok „lubelskiego” SL, partii ludowej. Właściwe cele olsztyńskiej wizyty Mikołajczyka nie są znane. Treść protokołu z przytoczonej konferencji odbytej w WUZ przedstawia jedynie jej gospodarczy wymiar. Nie należy jednak wykluczać celów politycznych, jak chociażby chęć przeciągnięcia części niezdecydowanych działaczy ludowych z Okręgu Mazurskiego do PSL, zob. B. Łukaszewicz, Polskie Stronnictwo Ludowe na Warmii i Mazurach w latach 1945-1947, Olsztyn 1991, ss. 21-22.

${ }^{57}$ AAN, MRiRR, 162/99, k. 6, Protokół konferencji wicepremiera S. Mikołajczyka z prezesem i naczelnikami WUZ w Olsztynie, 23 VIII $1945 \mathrm{r}$.

${ }^{58}$ APO, WUZ, 618/18, k. 49, Protokół z I Zjazdu kierowników PUZ województwa olsztyńskiego [właśc. Okręgu Mazurskiego] odbytego w dniach 29 i 30 X 1945 r. w Olsztynie.

${ }^{59}$ AAN, KC PPR, 295/XII-7, k. 50, Sprawozdanie z podróży służbowej Józefa Walnkiewicza do Okręgu Mazurskiego w dniach 17-27 I 1946 r. Z drugiej jednak strony miejscowi działacze PPR uskarżali się na związany w Okręgu Mazurskim z ludowcami Związek Gospodarczy Spółdzielni RP „Społem”. Stanisław Lange podczas odprawy w KC kierowników wydziałów rolnych KW powiedział: „Społem z papierkiem Ministerstwa [Rolnictwa i Reform Rolnych] zabiera Samopomocy [Chłopskiej] młyny. Za artykuły spożywcze bierze wyższą cenę niż inne spółdzielnie” - APO, KW PPR, 1073/144, k. 106, Protokół z odprawy w KC kierowników wydziałów rolnych KW PPR 6-7 XI 1945 r.). Warto dodać, że do września 1946 r. pełnomocnikiem Zarządu Głównego „Społem” w Okręgu Mazurskim/województwie olsztyńskim był Bohdan Wilamowski, członek Wojewódzkiego Komitetu SL. Co do samego Wilamowskiego, są jednak przypuszczenia dotyczące jego jednoczesnego członkostwa w PPR, zob. B. Łukaszewicz, op. cit., przyp. 107, s 118.
} 
Przeciwko komisarzom ziemskim i administratorom wystąpili także pracownicy referatów świadczeń rzeczowych w starostwach, podczas zjazdu ich przedstawicieli, który odbył sie 15-16 stycznia 1946 r. w Olsztynie. Jednym z głównych celów zjazdu było wypracowanie działań mających zapobiec deficytowi zbożowemu w 1946 r. Służyć temu miało m.in. ograniczenie ordynarii pracowników majątków państwowych z 16 q zboża rocznie na $16 \mathrm{~kg}$ na osobę i $25 \mathrm{~kg}$ na wyżywienie inwentarza miesięcznie. Pomysł ten zakładał więc ponad trzykrotne ograniczenie świadczeń rzeczowych ${ }^{60}$.

\subsection{Robotnicy rolni}

Obok braku pracowników bezpośrednio zarządzających majątkami, powszechnie odczuwano deficyt kadry robotniczej. Opisany powyżej niedostateczny stan bezpieczeństwa, a także fatalne warunków bytowe, tak jak w przypadku administratorów, rządcốw i buchălterỏw, skutecznie zniechęcały również potencjalnych polskich osadników do podjęcia pracy fizycznej w majątkach państwowych. Kadra robotnicza $w$ pierwszych powojennych miesiącach składała się niemal wyłącznie z ludności miejscowej - niemieckiej, Warmiaków i Mazurów, a także jeńców wojennych. Wynikało to z kilku powodów. Po pierwsze, część z nich przejmowała polska administracja $\mathrm{z}$ rąk sowieckich wraz z przekazywanymi majątkami, w których pracowali. Po drugie, zatrudnianie ich było spowodowane wspomnianym brakiem dostatecznej liczby Polaków - osadników z województw centralnych i przesiedleńców z Kresów Wschodnich. Po trzecie, dobrowolna lub przymusowa praca w majątku państwowym, w pierwszych tygodniach po zajęciu tych ziem przez wojska sowieckie, stwarzała szanse na uniknięcie deportacji do ZSRR, choć jej nie wykluczała ${ }^{61}$. Poza tym zatrudnienie w państwowym folwarku dawało możliwość zdobycia żywności.

\footnotetext{
${ }^{60}$ AAN, KC PPR, 295/XII-61, k. 31, Sprawozdanie Wydziału Rolnego KW PPR w Olsztynie, 19 I 1946 r.

${ }^{61}$ Po rozpoczęciu ofensywy zimowej Państwowy Komitet Obrony ZSRR wydał postanowienie (nr 7467 z 2 II 1945 r.) dotyczące deportowania z zajmowanych terenów Niemców w wieku 17-50 lat, zdolnych do noszenia broni. Mieli być oni zatrzymywani i wysyłani do ZSRR do batalionów pracy. Nie chodziło wyłącznie o zapewnienie bezpieczeństwa na tyłach przesuwających się frontów, lecz dostarczenie ok. 0,5 mln przymusowych robotników sowieckim kopalniom, przemysłowi i rolnictwu. Podstawą do przeprowadzenia „akcji oczyszczania tyłów" były rozkazy Berii, m.in. z 6 i 22 II 1945 r., stanowiące akty wykonawcze do wspomnianego postanowienia. Na Warmii i Mazurach od lutego 1945 r. większość osób gromadzono w obozach przejściowych. Tworzono je niekiedy w miejscach poniemieckich obozów i więzień (m.in. w Działdowie i Iławie). Nie dysponujemy dokładnymi danymi dotyczącymi liczby osób deportowanych z Prus Wschodnich w głąb ZSRR. Według rożnych szacunków, wywieziono od 60 do nawet 300 tys. osób. Zob.: A. Skrzypek, Mechanizmy uzależnienia. Stosunki polsko-radzieckie 1944-1957, Pułtusk 2002, ss. 69-74.; Z. Gertner, Obóz Nakazowo-Rozdzielczy NKWD w Działdowie, Rocznik Działdowski, 1995, ss. 164-179; L. Belzyt, Między Polska a Niemcami. Weryfikacja narodowościowa i jej następstwa na Warmii, Mazurach i Powiślu w latach 1945-1960, Toruń 1998, s. 51;
} 
Podkreślmy jednak w tym miejscu, że z powodu problemów werbunkowych przeważająca część miejscowej ludności zmuszana była do pracy siłą. Między innymi perspektywa braku rąk do pracy w majątkach, szczególnie podczas żniw w 1945 r., skłoniła Pełnomocnika Rządu Tymczasowego Jakuba Prawina do wydania 22 czerwca 1945 r. instrukcji, skierowanej do starostów, w sprawie postępowania z Niemcami. Jej głównym założeniem było wysiedlenie ludności niemieckiej mieszkającej w miastach Okręgu Mazurskiego do przejmowanych od Sowietów majątków ziemskich. Akcja miała być przeprowadzona między 1 a 10 lipca 1945 r. Instrukcja zobowiązywała starostów do przygotowania do 30 czerwca spisów Niemców zamieszkałych w miastach oraz, w porozumieniu z komisarzami ziemskimi, przygotowania spisu majątków, do których mieli zostać wysiedleni, wraz z przybliżonym limitem osób, których poszczególne majątki miały przyjaćc. Eskortowaniem Niemców z miast do majątków mieli zająć się funkcjonariusze MO. Ponadto starostowie mieli w porozumieniu z administratorami majątków wyznaczyć dozorców narodowości polskiej „do pilnowania Niemców przy pracy”. Wspomniana instrukcja nie obejmowała Niemców mieszkających na wsi. Tych, jak polecił Prawin, należało „na razie nie ruszać, natomiast kategorycznie im oświadczyć, że są odpowiedzialni osobiście za wykonanie wszelkich robót rolnych na czas (żniwa, omłot, obsiew itp.)"62. Termin wysiedlenia Niemców, wobec ogromnych problemów organizacyjnych w starostwach, początkowo przełożono na 10 lipca, a później zalecono wykonanie akcji sukcesywnie, w miarę możliwości organizacyjnych starostw i zarządów miejskich $^{63}$. Działania te, w efekcie późniejszych postanowień poczdamskich, stały się de facto pierwszym etapem akcji przesiedleńczej ludności niemieckiej do stref okupacyjnych w Niemczech.

Skutki czerwcowej instrukcji Prawina odnajdujemy w wielu późniejszych meldunkach i relacjach. W sprawozdaniu instruktora KC PPR Stanisława Fuszary z podróży służbowej do Okręgu Mazurskiego, odbytej w sierpniu 1945 r., czytamy: „Żniwa przeprowadza się przy użyciu Niemców”. Ponadto Fuszara informował o skierowaniu do prac polowych około 30 tys. byłych jeńców, przekazanych władzom polskim przez wojska sowieckie. Znaczna ich część była jednak niezdolna do pracy ze względu na zły stan zdrowia i wyczerpanie. W rzeczywi-

J. Czołgoszewski, Więziennictwo okresu stalinowskiego na Warmii i Mazurach w latach 1945-1956, Olsztyn 2002, ss. 73-77. W. Gieszczyński, Armia Sowiecka na Warmii i Mazurach w latach 1945-1948. Szkic do monografii, Zeszyty Naukowe Ostrołęckiego Towarzystwa Naukowego, 2013, nr 27, s. 61.

${ }^{62}$ APO, UP, 390/241, k. 11, Instrukcja Pełnomocnika Rządu Tymczasowego RP na Okręg Mazurski skierowana do starostów w sprawie postępowania z Niemcami, 22 VI 1945 r.; zob. też w: Warmiacy i Mazurzy w PRL. Wybór dokumentów. Rok 1945, przygotował do druku T. Baryła, Olsztyn 1994, dok. 31, s. 43.

${ }^{63}$ Ibidem, k. 13, Okólnik nr 16 Pełnomocnika Rządu w sprawie wykonania postanowień instrukcji o postępowaniu z Niemcami, 7 VIII $1945 \mathrm{r}$. 
stości stali się więc ciężarem dla administracji majątków ${ }^{64}$. Podobne informacje odnajdujemy w relacjach urzędników ziemskich. Jak donoszono z powiatu węgorzewskiego, akcję żniwną w 1945 r. „przeprowadzono częściowo ludnością miejscową - -, częściowo jeńcami z b.[yłej] armii niemieckiej”. Według tej relacji niemal trzecia część jeńców z powodów zdrowotnych nie nadawała się do pracy. W tym miejscu zaznaczyć warto, że w organizacji pracy jeńców stwierdzono szereg niedociągnięć ze strony administracji majątków. Często wysyłano jeńców pieszo, bez nadzoru oraz dostatecznego prowiantu i opieki medycznej, do majątków oddalonych o kilkadziesiąt kilometrów. Nic więc dziwnego, że ich liczba topniała. Jak zanotowano w sprawozdaniu do MRiRR, „przykładem niedołęstwa organizacyjnego” był fakt, że „na 300 jeńców wysłanych z Gierdaw, do Węgoborka przybyło $127^{\prime \prime 65}$. Z drugiej strony administracjom poszczególnych majątków nie zależało na pilnowaniu niewydajnych pracowników, stanowiących z punktu widzenia potrzeb aprowizacyjnych dodatkowy balast.

Podobne relacje spływały z innych powiatów. Komisarz ziemski z powiatu olsztyńskiego Marian Mirski donosif, że robotnicy w majątkach państwōwych rekrutowani byli przeważnie spośród jeńców wojennych i miejscowej ludności niemieckiej, a ta ostatnia też nie była wydajna, gdyż przeważali wśród niej ,starcy, kaleki i dzieci, do pracy mało przydatni". Jak zapisał Mirski, ludność niemiecka w wieku produkcyjnym, nadająca się do pracy „została w przeważającej ilości uprzednio wywieziona” do ZSRR. Komisarz ziemski uskarżał się, że pozostali byli „zabierani, nawet podczas wykonywania robót w majątkach, przez wojska radzieckie" ${ }^{\prime 66}$. Potwierdzają to także relacje olsztyńskiego WUBP: „przeprowadzenie akcji kopania ziemniaków w powiecie Rastembork utrudniają wojska radzieckie, gdyż pracującą ludność z pól aresztują nie pozwalając z pól wykopać ziemniaków, co grozi pozostaniem większej części ziemniaków na polu i - - [ich] zmarznięciem" ${ }^{67}$. Najczęściej Sowieci przenosili robotników niemieckich do pracy w majątkach rolnych, które nadal zajmowali. Zjawisko to miało szerszy zasięg i obejmowało obszar całego Okręgu Mazurskiego już od wiosny $1945 \mathrm{r}^{68}$

Po rozpoczęciu akcji wysiedlania ludności niemieckiej z Okręgu Mazurskiego do stref okupacyjnych na terenie Niemiec w majątkach pozostawali nieliczni robotnicy wywodzący się spośród zweryfikowanej ludności autochtonicznej i osadników. Według danych WUBP do końca 1945 r. wysiedlono ogółem niemal 40 tys. osób ${ }^{69}$.

${ }^{64}$ AAN, KC PPR, 295/XII-6, k. 139, Sprawozdanie Stanisława Fuszary z wyjazdu w sprawach organizacyjnych do Okręgu Mazurskiego od 21 do 26 VIII 1945 r.

${ }^{65}$ APO, WUZ, 618/4, k. 157, Sprawozdanie nr 12 z działalności Woj. Urzędu Ziemskiego w Olsztynie i powiatowych urzędów ziemskich oraz sytuacyjne za czas od 1 do 25 IX 1945 r., 27 IX 1945 r.

${ }^{66}$ Ibidem, 618/18, k. 34, Sprawozdanie kierownika PUZ w Olsztynie, 29 X 1945 r.

${ }^{67}$ AIPN Bi, 084/1, k. 61, Sprawozdanie miesięczne szefa WUBP w Olsztynie za okres 1 X - 31 X 1945 r.

${ }^{68}$ APO, WUZ, 618/18, k. 27v, Sprawozdanie z całokształtu działalności Pow. Urzędu Ziemskiego w Łuczanach do 30 IX $1945 \mathrm{r}$. 
Dane te potwierdzają zestawienia Wydziału Osiedleńczego w Urzędzie Pełnomocnika. W kolejnych miesiącach notowano spadek liczby ludności niemieckiej w stosunku do danych „wyjściowych” z końca czerwca 1945 r. (145,5 tys. osób): na koniec września spadek o 7310 osób, na koniec października o 23808 osób, na koniec grudnia o 39358 osób, marca 1946 r. o 55457 osób ${ }^{70}$. Wobec niepowodzeń równolegle prowadzonej akcji werbunkowej, państwowe majątki ziemskie zaczęły odczuwać „dotkliwy brak rąk roboczych”71. Zjawisko to było na tyle groźne dla ich funkcjonowania, że zwracali na nie uwage powiatowi komisarze ziemscy. Szef PUZ w Lidzbarku Warmińskim zaapelował nawet, aby „ludność niemiecką zdolną do pracy zatrzymać przez pewien czas, aż do napływu dostatecznej ilości repatriantów"72. Pracę w państwowych folwarkach zaczęli także porzucać Warmiacy i Mazurzy. Na to groźne zjawisko z punktu widzenia obsady kadrowej majątków państwowych zwracał uwagę komisarz ziemski z Nidzicy: „Pracownicy w majątkach szeregują się przeważnie z Niemców, którzy obecnie przyjmują polskie obywatelstwo i upominają się o zwrot gospodarstw poniemieckich, przekazanych polskim osiedleńcom i repatriantom"73. Zagrożeniem wpływającym na ubytek stanu zatrudnienia robotników w majątkach państwowych było więc nie tylko przesiedlanie Niemcówza Odrę, lecz takze weryfikacja narodowościowa autochtonów, dzięki której mogli odzyskiwać utracone gospodarstwa i na nie powracać ${ }^{74}$. Początkowa praca w majątkach państwowych była więc dla nich sposobem na przetrwanie „trudnych czasów”.

$\mathrm{Na}$ negatywne skutki wysiedleń ludności niemieckiej, w kontekście niepowodzeń działań werbunkowych, zwracali uwagę także inni urzędnicy tere-

${ }^{69}$ AIPN Bi, 084/1, k. 174, Sprawozdanie miesięczne za okres 1-29 XII 1945 r.

${ }^{70}$ Dodajmy, że „ubytek” ludności niemieckiej, nie musiał być skutkiem wyłącznie wysiedleń. W tym samym czasie (do końca marca 1946 r.) nastąpił wzrost liczby zweryfikowanych Warmiaków i Mazurów o 52447 osób - obliczenia własne na podst.: APO, KW PPR, 1073/144, k. 32, Dane statystyczne dotyczące ludności na koniec czerwca 1945 r.; ibidem, k. 49, Liczba ludności w Okręgu Mazurskim według stanu na 1 X 1945 r.; ibidem, k. 85, Liczbowy stan ludności w Okręgu Mazurskim według stanu na 1 XI 1945 r.; ibidem, k. 115, Statystyczny wykaz stanu ludności w Okręgu Mazurskim za czas 1 XII do 31 XII 1945 r.; ibidem, k. 144, Zaludnienie Okręgu Mazurskiego do dnia 31 III 1946 r. Podobną liczbę (51713) Warmiaków i Mazurów zweryfikowanych w tym samym okresie uzyskamy opierając się na zestawieniach L. Belzyta, op. cit., tab. 3, s. 80.

${ }^{71}$ APO, WUZ, 618/18, k. 34, Sprawozdanie kierownika PUZ w Olsztynie, 29 X 1945 r.

${ }^{72}$ Ibidem, 618/4, k. 193, Protokół ze zjazdu komisarzy ziemskich woj. mazurskiego odbytego 6 II 1946 r. w Olsztynie.

${ }^{73}$ Ibidem, 618/18, k. 44v, Sprawozdanie PUZ w Niborku za czas 1 IV do 25 X 1945 r.

${ }^{74}$ Wielu autochtonów, będących właścicielami zajętych przez osadników gospodarstw, było z czasem weryfikowanych jako Polacy. Powstało więc zjawisko tzw. gospodarstw spornych. Problem starano się rozwiązać unieważniając akty nadania wydawane wcześniej niektórym osadnikom, a także proponując autochtonom przejęcie innych gospodarstw. Do 1948 r. liczba spornych gospodarstw wyniosła 6355, zob. B. Wilamowski, Studia założeń i początków osadnictwa rolnego na terenie woj. olsztyńskiego w latach 1945-1948, Olsztyn 1963, maszynopis pracy doktorskiej, s. 377, Biblioteka OBN, Zbiory Specjalne. W poszczególnych latach problem tych gospodarstw starano się rozwiązywać na bieżąco. Stąd w niektórych publikacjach liczba zarejestrowanych gospodarstw spornych wyraża wielkości na dany rok i różni się od przytoczonej przez Wilamowskiego, zob.: W. Wrzesiński, Proces zasiedlania województwa olsztyńskiego w latach 1945-1949, w: Problemy rozwoju gospodarczego i demograficznego Ziem Zachodnich w latach 1945-1958, red. B. Gruchman, J. Ziółkowski, Poznań 
nowi. Komisarz ziemski z powiatu węgorzewskiego alarmował: „wobec likwidacji na naszym terenie ludności niemieckiej, [zjawisko to] będzie dla wszystkich naszych poczynań gospodarczych wprost katastrofalne"75. Domyślać się można, że „likwidacja” oznaczała przesiedlenia ludności niemieckiej i weryfikację narodowościową Warmiaków i Mazurów. Problem był bardzo poważny i powszechny w skali Okręgu Mazurskiego. W listopadowym sprawozdaniu z działalności WUZ informowano, że w niektórych powiatach „z braku pracowników około $50 \%$ zboża pozostało na pniu nie zebranego"76.

Do czasu, gdy nadzór nad majątkami państwowymi sprawowały urzędy ziemskie, wobec fiaska akcji werbunkowej, ich funkcjonowanie w znacznym stopniu opierało się na sile roboczej, którą stanowiła ludność niemiecka. W majątkach (o powierzchni powyżej 100 ha), które WUZ przekazał na terenie Okręgu Mazurskiego Państwowym Nieruchomościom Ziemskim, zatrudnionych było blisko 7 tys. pracowników, z tego ponad 6,5 tys. stanowili robotnicy rolni. W kwietniu $1946 \mathrm{r}$., gdy przesiedlenia ludności niemieckiej trwały od kilku miesięcy, w majątkach państwowych na Warmii i Mazurach wciąż pracōwało 5177 rōbōtników niemieckich (tabela), co stanowiło 79\% ogółu pracowników fizycznych. W nieruchomościach ziemskich objętych obszarem działania Zarządu Okręgowego PNZ w Olsztynie wskaźnik ten był jeszcze wyższy i wynosił ponad $84 \%{ }^{77}$.

Kadry w gospodarstwach Zarząáów Okręgowych PNZ w Olsztynie i Giżycku przejętych od Wojewódzkiego Urzędu Ziemskiego w Olsztynie (stan z kwietnia 1946 r.)

\begin{tabular}{|c|c|c|c|c|c|c|c|c|c|}
\hline \multirow[b]{3}{*}{$\begin{array}{c}\text { Zarząd } \\
\text { Okręgu } \\
\text { PNZ }\end{array}$} & \multirow[b]{3}{*}{ Powiat } & \multicolumn{5}{|c|}{ Pracownicy umysłowi } & \multicolumn{3}{|c|}{ Pracownicy fizyczni } \\
\hline & & \multirow[b]{2}{*}{ 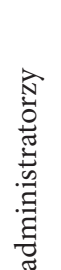 } & \multirow{2}{*}{ 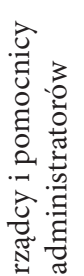 } & \multirow[b]{2}{*}{ 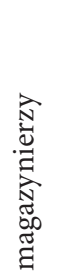 } & \multirow[b]{2}{*}{ 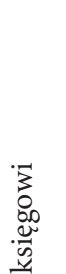 } & \multirow[b]{2}{*}{.$\vec{\Xi}$} & \multirow[b]{2}{*}{ 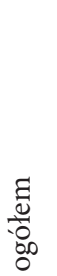 } & \multicolumn{2}{|c|}{ w tym: } \\
\hline & & & & & & & & $\frac{\hat{\tilde{J}}}{\frac{\pi}{0}}$ & 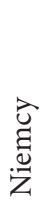 \\
\hline
\end{tabular}

1960, s. 188, autor podaje liczbę 1258 gospodarstw spornych; K. Pietrzak-Pawłowski, Od Prus Wschodnich do województwa olsztyńskiego 1945-1947, Przegląd Zachodni, 1947, nr 2, s. 135, autor podaje liczbę 1100 gospodarstw; S. Żyromski, Procesy migracyjne w województwie olsztyńskim w latach 1945-1949, Olsztyn 1971, s. 84, autor podaje liczbę 2120 gospodarstw spornych. Dodajmy w tym miejscu, że łączna liczba wszystkich gospodarstw chłopskich na terenie Warmii i Mazur do 1939 r. wynosiła nieco ponad 68 tys.

${ }^{75}$ APO, WUZ, 618/18, k. 23, Sprawozdanie powiatowego komisarza ziemskiego w Węgoborku za czas 30 IX 29 X 1945 r.

${ }^{76}$ Ibidem, 618/4, k. 171, Sprawozdanie nr 13 z działalności Woj. Urzędu Ziemskiego w Olsztynie i powiatowych urzędów ziemskich oraz sytuacyjne za czas od 25 IX do 31 X 1945 r., 19 XI 1945 r.

77 AAN, ZC PNZ, 429/1642, k. nlb., Zatrudnienie w gospodarstwach objętych zespołami ZO PNZ w Olsztynie, Tablica IV, 19 IV 1946 r. 


\begin{tabular}{|c|c|c|c|c|c|c|c|c|c|}
\hline \multirow{7}{*}{ Giżycko } & Mrągowo & 5 & 19 & 2 & 2 & - & 720 & 186 & 534 \\
\hline & Kętrzyn & 6 & 26 & 6 & 4 & 4 & 906 & 176 & 738 \\
\hline & Węgorzewo & 2 & 4 & - & - & 5 & 53 & 42 & 11 \\
\hline & Reszel & 3 & 12 & 3 & 1 & - & 217 & 68 & 149 \\
\hline & Pisz & 4 & 3 & 1 & - & - & 8 & b.d. & b.d. \\
\hline & Giżycko & 7 & 16 & 16 & 3 & - & 296 & 212 & 84 \\
\hline & Razem: & 27 & 94 & 28 & 10 & 9 & 2200 & 680 & 1512 \\
\hline \multirow{7}{*}{ Olsztyn } & Bartoszyce & 2 & 22 & - & 1 & - & 518 & 18 & 500 \\
\hline & Braniewo & 3 & 7 & - & - & - & 74 & - & 74 \\
\hline & Górowo Ił. & 1 & 2 & 1 & - & - & 55 & - & 55 \\
\hline & Lidzbark & 5 & 37 & - & 5 & 3 & 585 & 10 & 575 \\
\hline & Morąg & 9 & 29 & 2 & 5 & 2 & 1092 & 37 & 1055 \\
\hline & Nidzica & 2 & 17 & 1 & 1 & - & 203 & 121 & 82 \\
\hline & Olsztyn & 5 & 13 & - & 4 & 1 & 179 & 176 & 3 \\
\hline \multirow{5}{*}{$\sqrt{3} 3 \sqrt{3}$} & Ostróda & 5 & 34 & 4 & 3 & 4 & 661 & 198 & 463 \\
\hline & Pasłęk & 4 & 12 & - & 1 & 5 & 811 & 7 & 804 \\
\hline & Susz & 1 & 7 & - & 1 & - & 107 & 53 & 54 \\
\hline & Szczytno & 2 & 7 & -2 & 2 & $1 \mathrm{c}$ & 68 & 68 & - \\
\hline & Razem: & 39 & 187 & 8 & 23 & 16 & 4353 & 688 & 3665 \\
\hline \multicolumn{2}{|c|}{ Ogółem: 11} & 66 & 281 & 36 & 33 & 25 & 6553 & 1368 & 5177 \\
\hline
\end{tabular}

Źródło: zestawienie własne na podst.: AAN, ZC PNZ, 429/1642, k. nlb.; Zatrudnienie w gospodarstwach objętych zespołami ZO PNZ w Giżycku, Tablica IV a, 19 IV 1946 r.,; ibidem, k. nlb.; Zatrudnienie w gospodarstwach objętych zespołami ZO PNZ w Olsztynie, Tablica IV.

Dodajmy w tym miejscu, że wobec niemieckiej ludności miejscowej, przymusowo zatrudnionej $\mathrm{w}$ majątkach państwowych, administratorzy nie stosowali warunków określonych we wspomnianym układzie zbiorowym pracy z 5 czerwca 1945 r. Za wykonywaną pracę rządcy i administratorzy, w miarę możliwości majątków i potrzeb robotników, samodzielnie ustalali wysokość świadczeń w naturze, które miały zapewnić im przetrwanie. Podczas wspomnianego już I Zjazdu Komisarzy Powiatowych Urzędów Ziemskich, na pytanie wiceministra Stanisława Bieńka, skierowane do komisarza PUZ w Olsztynie: „Czy na majątkach jest służba?”, padła odpowiedź: „Majątki przekazano bez ludzi. Do prac brano przymusowo z okolicznych wsi, nie płacąc nic za roboty"78. Abstrahując od użytego przez wiceministra Bieńka terminu ,służba”, dla wielu urzędników przymusowe zatrudnianie Niemców, po doświadczeniach ostatniej wojny, początkowo wydawało się naturalne. Podobne relacje spływały $\mathrm{z}$ innych powiatów. Komisarz PUZ z Ostródy, pytany w tym samym kontekście o robotników w majątkach państwowych, odpowiedział: „Robotnikami są Niemcy. Po-

${ }^{78}$ APO, WUZ, 618/18, Protokół z I Zjazdu kierowników PUZ województwa olsztyńskiego [właśc. Okręgu Mazurskiego] odbytego w dniach 29 i 30 X 1945 r. w Olsztynie, k. 48v. 
lacy są fachowcami”, co pozwala domyślać się, że nadzorowali oni pracę przymusowo zatrudnionych Niemców ${ }^{79}$. Jednak po kilku miesiącach administratorzy zaczęli zdawać sobie sprawę, że przymus i brak zasad dotyczących wynagrodzenia za pracę obniżały wydajność niemieckich robotników rolnych. Z powiatów donoszono: „służba folwarczna jest krzywdzona z powodu braku żywności. Nie ma mleka, cukru, soli. Trzeba jej koniecznie dać przydziały aprowizacyjne"80. W innej relacji podkreślano, że robotnicy w wielu powiatach „głodni i wycieńczeni nie mogli pracować" ${ }^{81}$. W grudniu 1945 r. komisarz ziemski z Lidzbarka Warmińskiego, zgłosił prezesowi WUZ potrzebę ustalenia stawek zarobkowych w gotówce i naturaliach, które miały umożliwić robotnikom niemieckim „normalną pracę" i „egzystencję" ${ }^{2}$. Do końca interesującego nas okresu, czyli do lutego 1946 r., gdy majątki ziemskie pozostawały pod administracją urzędów ziemskich, stawki te nie zostały ustalone.

Ciężkie warunki skutecznie odstraszały także polskich robotników sezonowych. Wielu z tych, którzy byli werbowani w województwach centralnych, rezygnowało już w czasie podróźy, inni po przyjeździè na miejsce. Znamienna jest relacja z września 1945 r. dotycząca grupy sezonowych robotników żniwnych udających się z Mławy do Węgorzewa, których liczba topniała w miarę zbliżania się do miejsca przeznaczenia. Z Mławy wyruszyło 120 osób, a do Węgorzewa dotarło 25, z których „następnego dnia uciekło 24, pozostał tylko przewodnik” ${ }^{3}$. Zdaniem komisarzy ziemskich, główną przyczyną ucieczki robotników sezonowych był „brak należytej opieki”.

\section{Konsekwencje problemów kadrowych}

Trudne i niebezpieczne warunki sprawiały, że komisarze ziemscy zaniżali kryteria doboru kandydatów do pracy na stanowiska administratorów, rządców czy buchalterów w majątkach państwowych. Starali się przede wszystkim jak najszybciej zabezpieczyć majątki ziemskie przed dalszym rabunkiem, niszczeniem i dewastacją. Stąd początkowo priorytetem było niezwłoczne „obsadzenie" majątku. Przy ogromnych potrzebach personalnych dokonywano szybkiego

\footnotetext{
${ }^{79}$ Ibidem.

${ }^{80}$ Ibidem, 618/4, k. 195, Protokół ze zjazdu komisarzy ziemskich woj. mazurskiego odbytego 6 II 1946 r. w Olsztynie.

${ }^{81}$ Ibidem, k. 155, Sprawozdanie nr 12 z działalności Woj. Urzędu Ziemskiego w Olsztynie i powiatowych urzędów ziemskich oraz sytuacyjne za czas od 1 do 25 IX 1945 r., 27 IX 1945 r.; Ibidem, 618/34, Pismo komisarza ziemskiego PUZ w Lidzbarku Warmińskim do WUZ, 10 XII 1945 r., k. 31.

${ }^{82}$ Ibidem, 618/34, Pismo komisarza ziemskiego PUZ w Lidzbarku Warmińskim do WUZ, 10 XII 1945 r., k. 31.

${ }^{83}$ Ibidem, 618/4, k. 157, Sprawozdanie nr 12 z działalności Woj. Urzędu Ziemskiego w Olsztynie i powiatowych urzędów ziemskich oraz sytuacyjne za czas od 1 do 25 IX 1945 r., 27 IX 1945 r.
} 
naboru, w wyniku czego posady otrzymywały osoby w niedostateczny sposób sprawdzone, nieprzygotowane pod względem fachowym. Ich rola, jak już wspomniano, sprowadzała się do funkcji stróży chroniących mienie państwowe.

W urzędach ziemskich zdawano sobie sprawę z negatywnej selekcji i z konieczności ją akceptowano. Poważne trudności w wyszukaniu odpowiednich kandydatów na administratorów zmuszały pracowników urzędów ziemskich do przyjmowania osób nieprzygotowanych pod względem fachowym i „małowartościowych pod względem moralnym”. Z powodu braku fachowców, komisarze ziemscy zmuszeni byli „patrzeć przez palce” na nadużycia administratorów, ponieważ, jak tłumaczyli: „zwolnienie pracownika przyniesie jeszcze większe szkody, jeżeli majątek pozostanie bez żadnego dozoru" ${ }^{84}$. Ubolewano, że pracownicy uczciwi i odpowiednio przygotowani nie wytrzymywali warunków materialnych i rezygnowali z pracy ${ }^{85}$. Narzekano więc, że majątki były obsadzone przez ludzi bez odpowiednich kwalifikacji, „patrzących na pracę pod kątem widzenia własnych interesów i korzyści". Poza tym nie do końca w roli administratorów, a właściwie dozorców, sprawdzali się Mazurzy, którzy, "nie miëli odwagi się bronić” i zbyt łatwo, bez oporu pozwalali grabić majątki państwowe sowieckim maruderom ${ }^{86}$.

Na błędy popełniane w naborze kandydatów na stanowiska administratorów i rządców zwrócono uwagę podczas inspekcji międzyministerialnej dokonanej w majątkach ziemskich na terenie Okręgu Mazurskiego na przełomie września i października 1945 r. Stwierdzono, że niektóre nieruchomości ziemskie, znajdujące się w administracji urzędów ziemskich, były obsadzane „elementem nieodpowiednim”, często przez osoby pochodzenia obcego, np. Niemców lub Litwinów ${ }^{87}$. Prezes WUZ ostrzegał szefów powiatowych urzędów ziemskich, że po stwierdzeniu podobnych przypadków będzie ich „zamykał”88. Z powodu braku osób przygotowanych pod względem fachowym polecono, aby stanowiska administratorów i rządców tymczasowo były powierzane Polakom - robotnikom rolnym, posiadaczom gospodarstw rolnych, czyli, jak stwierdzono, osobom „obznajmionym z rolnictwem”" Sugestie Ministerstwa Rolnictwa i Reform Rolnych, kierowanego wówczas przez Stanisława Mikołajczyka, nie nakazywały wprost stosowania klucza „klasowego”,

\footnotetext{
${ }^{84}$ Ibidem, k. 194, Protokół ze zjazdu komisarzy ziemskich woj. mazurskiego odbytego 6 II 1946 r. w Olsztynie.

${ }^{85}$ Ibidem, k. 186, Sprawozdanie nr 14 z działalności Wojewódzkiego Urzędu Ziemskiego w Olsztynie i powiatowych urzędów ziemskich oraz sytuacyjne za czas od 1 XI do 30 XI 1945 r., 29 XII 1945 r.

${ }^{86}$ Ibidem, 618/34, k. 196, Sprawozdanie Jana Koziełł-Poklewskiego p.o. komisarza PUZ w Morągu do WUZ w Olsztynie, 22 X 1945 r.

${ }^{87}$ Ibidem, 618/4, k. 115, Protokół z inspekcji majątków ziemskich na terenie Okręgu Mazurskiego przeprowadzonej przez komisję międzyministerialną, 12 X $1945 \mathrm{r}$.

${ }^{88}$ Ibidem, 618/18, k. 55v, Protokół z I Zjazdu Kierowników PUZ Województwa Olsztyńskiego [właśc. Okręgu Mazurskiego] odbytego w dniach 29 i 30 X 1945 r. w Olsztynie.

${ }^{89}$ Ibidem, 618/4, k. 115, Protokół z inspekcji majątków ziemskich na terenie Okręgu Mazurskiego przeprowadzonej przez komisję międzyministerialną, 12 X 1945 r.
} 
lecz decydujący miał być klucz „narodowy”. Otwarcie nie wykluczano polskich ziemian. Dlatego spora część stanowisk administratorów i rządców, szczególnie w powiatach lepiej zagospodarowanych i bardziej zaludnionych, m.in. w wyniku napływu przesiedleńców z Kresów Wschodnich, była powierzona ziemianom. Komisarz PUZ w Ostródzie, ziemianin Jerzy Binzer, podczas pierwszego zjazdu kierowników PUZ w Olsztynie, na pytanie wiceministra rolnictwa i reform rolnych Stanisława Bieńka: „z jakiego elementu składają się zaangażowani administratorzy majątków?” - odpowiedział: „Dużo bardzo ziemian, poza tym b.[yli] administratorzy i rządcy" ${ }^{\prime \prime}$. Co ciekawe, nie spotkało się to z krytyką żadnego z uczestników wspomnianego zjazdu, co więcej, Binzer był stawiany innym komisarzom ziemskim jako wzór, osoba, która sprawnie i skutecznie doprowadziła do uruchomienia majątków ziemskich na swoim terenie.

Bez wątpienia ziemianie i administratorzy przedwojennych dóbr ziemskich byli-osobami spełniającymi kryteria wykształcenia, fachowości i doświadczenia w pracy na wielkopowierzchniowych gospodarstwach. Stanowiska na terenach nowo włączonych do Polski, oddalonych od Warszawy, stały się dla wielu z nich swoistą „ucieczką", pozwalały „ukryć się”, z nadzieją na przeczekanie „niepewnych" czasów, po nastaniu nowej władzy. Poza tym, na tych terenach niemal do wszystkich majątków ziemskich poszukiwano zarządców, w przeciwieństwie do tzw. ziem dawnych, na których w wyniku reformy rolnej „obszarnicze” folwarki na ogół rozparcelowywano. Szansa na zdobycie posady na tzw. Ziemiach Odzyskanych była więc duża.

Wydaje się, że wpływ na powierzanie ziemianom stanowisk w aparacie rolnym i administracji poniemieckich majątków wywarły dwa czynniki. Po pierwsze: autonomia pracowników urzędów ziemskich wobec lokalnej administracji ogólnej; po drugie, względy merytoryczne. Zgodnie ze wspomnianym wyżej dekretem z 15 sierpnia 1944 r. o organizacji wojewódzkich i powiatowych urzędów ziemskich, stanowiły one sieć administracji niezespolonej, bezpośrednio podlegającą MRiRR ${ }^{11}$. W Okręgu Mazurskim nie podlegały więc władzy pełnomocnika rządu Jakuba Prawina, związanego z PPR, lecz ministra rolnictwa i reform rolnych, tym samym nie mogły być kontrolowane przez komunistów w takim stopniu, w jakim tego ci ostatni oczekiwali. Ministerstwo Rolnictwa i Reform Rolnych zdominowane było co prawda do końca czerwca 1945 r. przez „lubelskie” SL, choć w prace nad odbudową rolnictwa włączyli się także działacze ludowi popierający konspiracyjne SL „Roch”. W terenie, w urzędach ziemskich,

\footnotetext{
${ }^{90}$ Ibidem, 618/18, k. 48v, Protokół z I Zjazdu Kierowników PUZ Województwa Olsztyńskiego [właśc. Okręgu Mazurskiego] odbytego w dniach 29 i 30 X 1945 r. w Olsztynie.

${ }^{91}$ Dz. U. 1944, Nr 2, poz. 4.
} 
najczęściej stanowiska były powierzane ludowcom, osobom sympatyzującym z szeroko rozumianym ruchem ludowym, bądź w inny sposób powiązanym z wsią. Po powrocie Mikołajczyka i przejęciu przez niego teki ministra rolnictwa i reform rolnych oraz funkcji wicepremiera wielu z nich przeszło z „lubelskiego” SL do ujawnionego SL „Roch”, później PSL, lub z nim sympatyzowało. Komuniści z coraz większą nieufnością przyglądali się więc, jak to określali, „zaśmieconej” kadrze urzędów ziemskich ${ }^{92}$.

Przedstawione wyżej ogromne problemy, jakie napotykano przy werbunku kadr do poniemieckich folwarków, skłaniały komisarzy ziemskich do przyjmowania do pracy osób różnych. Chętnie na stanowiskach administratorów zatrudniali ziemian, ale niektórzy z nich także byli ziemianami, np. wspomniany komisarz PUZ w Ostródzie Jerzy Binzer, czy p.o. komisarza PUZ w Moragu Jan Koziełł-Poklewski. Angażowanie osób fachowo przygotowanych, świadczyć może o tym, że urzędnikom ziemskim, sympatyzującym z PSL, zależało na sprawnym i efektywnym funkcjonowaniu państwowych gospodarstw, których część, przypomnijmy, miała być poddana parcelacji. Możnā podejrzewać, że pracownicy urzędów ziemskich, początkowo odcięci od wpływów PPR, mieli dla swych poczynan personalnych „ciche przyzwolenie”, swoisty "parasol ochronny” ze strony Mikołajczyka, tym bardziej że, jak wspomniano, wyludnienie na Warmii i Mazurach było ogromne, łatwo więc można było umotywować powierzanie stanowisk administratorów lub rządców ziemianom. Jednak takie osoby na stanowiskach kierowniczych w majątkach nie były akceptowane przez komunistów. Nie ma wątpliwości, że zarzuty wysuwane przez działaczy PPR, dotyczące „nieodpowiednich” kadr w urzędach ziemskich i majątkach państwowych, wynikały z pobudek politycznych, a nie merytorycznych.

Dodajmy w tym miejscu, że na sporą część ziemian, którzy znaleźli się w aparacie zarządzającym w państwowych folwarkach, szczególną uwagę zwracali funkcjonariusze olsztyńskiego aparatu UB. W przeciwieństwie do jednostek gospo-

\footnotetext{
${ }^{92}$ Stanisław Lange, kierownik Wydziału Rolnego KW PPR w sprawozdaniu do KC z kwietnia 1946 r. zapisał: „Najbardziej zaśmieconym aparatem przez powyższe elementy [jawnych lub zakonspirowanych członków PSL, którzy mieli być powiązani z NSZ - R.G.], jest u nas aparat gospodarczy, urzędy ziemskie. Jaskrawym przykładem jest właśnie akcja siewna na majątkach państwowych. Tam oni wykazują swoje mistrzostwo sabotażową robotą" (AAN, KC PPR, 295/XII-61, k. 68, Sprawozdanie Wydziału Rolnego KW PPR, 11 IV 1946 r.). Z kolei w sprawozdaniu za okres od sierpnia 1945 do kwietnia 1946 r. Lange zanotował: „- - jeżeli Partii naszej nie uda się w najbliższym czasie przeprowadzić czystki aparatu gospodarczego, szczególnie w urzędach ziemskich, w administracji majątków państwowych i to odgórnie, niebezpieczeństwo dalszego zaśmiecania tego aparatu jeszcze bardziej wzrośnie i wzmoże się jeszcze usilniej akcja sabotażowa ze strony tych elementów, szczególnie zaś w urzędach ziemskich i majątkach państwowych. Mówię z całą powagą, sytuacja dojrzała, by uderzyć w dzwon alarmowy" (APO, KW PPR, 1073/127, k. 81, Sprawozdanie Wydziału Rolnego KW PPR za okres 1 VIII 1945 - 14 IV 1946 r.). Przypomnijmy, że Lange sprawozdania te pisał w okresie szybkiej rozbudowy organizacyjnej PSL w Okręgu Mazurskim. Do końca marca 1946 r., obok struktur wojewódzkich, istniało już 14 zarządów powiatowych PSL. Zob. B. Łukaszewicz, op. cit., ss. 39-44.
} 
darczych prowadzonych przez osoby o „właściwym” pochodzeniu społecznym, przyczyny wszelkich trudności i niepowodzeń w majątkach administrowanych przez ziemian funkcjonariusze UB przypisywali ich złej woli, celowej i rozmyślnej działalności na szkodę gospodarstw i państwa. Ten swoisty relatywizm ocen wynikający ze z góry założonej tezy, o wrogiej postawie ziemian wobec państwa i ich nieuczciwości, którą wystarczyło „potwierdzić” doniesieniami, informacjami tajnych współpracowników i odpowiednio prowadzonym śledztwem, polegającym m.in. na wymuszaniu i fabrykowaniu zeznań świadków, w efekcie prowadził do nieprawdziwych zarzutów. W pierwszych dniach, po przekazaniu przez WUZ majątków ziemskich PNZ, szef olsztyńskiego WUBP w raporcie do MBP zanotował: „Ogólnie jest opinia, że majątki państwowe nie wypełniają zadania w całej rozciągłości, ponieważ są administrowane przez byłych właścicieli majątków lub też administratorów majątków przedwojennych, którzy nie dokładają, można powiedzieć, rozmyślnie swojej inicjatywy do zagospodarowania oddanych im pod nadzór majątków, a raczej wykorzystują wszystko, aby było jak najgorzej" "93. Wobec administratorów i rządcôw wywodzących się spośród chłopów, robotników przedwojennych folwarków lub osób pochodzenia robotniczego, niemających nic wspólnego z rolnictwem, podobnych informacji z tege okresu w aktach UB nie odnajdujemy, w przeciwieństwie do bardziej wiarygodnych w tym względzie materiałów wytworzonych przez urzędy ziemskie.

Jednak osobami pochodzenia ziemiańskiego urzędy ziemskie nie były w stanie obsadzić wszystkich stanowisk kierowniczych w majątkach. Zapotrzebowanie było ogromne, a do tego, jak już wspomniano, istotną rolę odgrywał czas, gdyż zwalnianym przez Sowietów majątkom należało zapewnić opiekę przed szabrem i dewastacją. W związku z tym pracownicy urzędów ziemskich, działający pod presją czasu, świadomi złego stanu bezpieczeństwa i trudnych warunków bytowych, obok doświadczonych ziemian, przyjmowali w zasadzie wszystkich chętnych, którzy wyrazili wolę objęcia stanowiska w administracji majątków. W efekcie powyższe działania doprowadziły do wyraźnej niejednorodności tej kategorii pracowników. Z jednej strony na czele poszczególnych majątków znaleźli się ziemianie, często inżynierowie rolnicy, świetni fachowcy, doświadczeni w prowadzeniu własnych i cudzych majątków ziemskich przed wojną. $Z$ drugiej, wiele stanowisk objęli ludzie przypadkowi, niefachowi, rządni szybkiego wzbogacenia się. Ten swoisty dualizm wśród kadry kierowniczej w majątkach ziemskich wpłynął na niejednoznaczną ocenę ogólnej działalności państwowych gospodarstw. Dodajmy, że spora część osób przypadkowych, bez przygotowania 
fachowego, dość szybko wykruszała się spośród kadry zarządzającej majątkami państwowymi. W ich miejsce przychodzili nowi, nie zawsze lepiej przygotowani do tego, aby podołać zadaniom związanym z prowadzeniem majątku ziemskiego. Rotacja na tych stanowiskach, w pierwszych miesiącach funkcjonowania majątków państwowych i później, była niezwykle duża.

Jednym z warunków szybkiego zagospodarowania i sprawnego funkcjonowania majątków ziemskich na Warmii i Mazurach było zapewnienie im odpowiedniej obsady kadrowej. Już od czasu przekazywania przez wojska sowieckie poniemieckich folwarków polskiej administracji rolnej, zadaniu temu urzędnicy ziemscy nie potrafili sprostać. Przyczyn było kilka, a problem dotyczył dwóch kategorii pracowników: administracji i siły roboczej. Zgodnie z założeniem, docelowo, w majątkach pracować miała ludność polska napływowa oraz ludność miejscowa uznana za polską. Jednak początkowo, z powodu ogromnego niedoludnienia Okręgu Mazurskiego, władze postanowiły stanowiska pracowników umysłowych w majątkach państwowych powierzać Polakom (osadnikom i zweryfikowanym autochtonom), natomiast obsadę załóg robotniczych tymczasowo stanowić miała ludność niemiecka, oczekująca na przesiedlenie, którą sukcesywnie zastępować mieli miejscowi i napływowi Polacy. Oba założenia było niezwykle trudno zrealizować.

Pracownikom urzędów ziemskich nie udało się zapewnić pełnej obsady personelu administracyjnego w majątkach, na co decydujący wpływ miał zły stan bezpieczeństwa i fatalne warunki bytowe. $Z$ jednej strony zniechęcały tych, którzy podjęli pracę, z drugiej zaś, odstraszały potencjalnych kandydatów. W momencie przekazywania majątków ziemskich zarządom okręgowym PNZ w marcu 1946 r. ponad dwie trzecie gospodarstw nie posiadało kadry zarządzającej: administratorów, rządców i pomocników administratorów. Nie udało się także zapewnić dostatecznej ilości pracowników fizycznych, mimo skierowania do pracy ludności niemieckiej. Niewspółmierny ze spodziewanym ruch osadniczy, przy jednoczesnej akcji przesiedleńczej Niemców, sprawił, że permanentnym problemem majątków państwowych był stały niedobór siły roboczej. O braku chętnych do pracy w państwowych gospodarstwach wśród polskiej ludności miejscowej i napływowej świadczy fakt, że jeszcze w kwietniu 1946 r., po trwającej od kilku miesięcy akcji przesiedleńczej ludności niemieckiej, robotnicy niemieccy stanowili niemal 80\% załóg majątków ziemskich. Zakładanego, we wspomnianym wyżej grudniowym okólniku ministra rolnictwa i reform rolnych, średniego stanu zatrudnienia, wynoszącego: 1 robotnik rolny na 16 ha gruntów ornych, nie udało się osiągnąć. Według statystyki PNZ, dotyczącej go- 
spodarstw przejętych od urzędów ziemskich, średnia ta w marcu 1946 r. wynosiła: 1 robotnik rolny na 52 ha gruntów ornych ${ }^{94}$.

Tak niski stan zatrudnienia pracowników administracji i robotników rolnych w majątkach ziemskich, zajmujących, jak już wspomniano $35-37 \%$ powierzchni gruntów ornych w Okręgu Mazurskim, nie stwarzał szans na szybki rozwój państwowych gospodarstw, nie wpływał na poprawę aprowizacji, w znaczący sposób hamował ruch osadniczy, a także spowalniał ogólny rozwój gospodarczy Warmii i Mazur.

Polityka personalna urzędów ziemskich przyniosła także inne implikacje. Większość ziemian oraz przedwojennych administratorów i rządców, zatrudnionych w urzędach ziemskich i majątkach państwowych, przeszła w lutym i marcu 1946 r., wraz z majątkami, w których pracowali, do Państwowych Nieruchomości Ziemskich, w których do stycznia i lutego 1947 r., a więc do czasu wyborów sejmowych i złożenia przez Mikołajczyka teki ministra rolnictwa i reform rolnych, istniał sprzyjający klimat dla osób pochodzenia ziemiańskiego. Osoby te, juz od przełomu 1947 i 1948 r., stały się obiektem ataków i čzystek personalnych dokonywanych wobec kadry PNZ, a nierzadko także fałszywych oskarżeń, procesów pokazowych, w wyniku których zasądzano im surowe kary, z karą smierci włącznie. Przykładem „oczyszczania” kadr w administracji majątków państwowych oraz represji wobec osób o „nieodpowiednich” życiorysach i pochodzeniu społecznym było aresztowanie i proces pokazowy kierownictwa Zarządu Okręgowego PNZ w Olsztynie, dyrektora Jana Koziełł-Poklewskiego (byłego komisarza ziemskiego w Moragu), naczelnika Wydziału Rolnego Jerzego Binzera (byłego komisarza ziemskiego w Ostródzie) i kierownika Referatu Personalnego Stefana Kossakowskiego. Całej trójce postawiono zarzuty z art. 39 dekretu z 13 czerwca 1946 r. o przestępstwach szczególnie niebezpiecznych w okresie odbudowy Państwa. Obwiniono ich o niegospodarność, w wyniku której majątki państwowe miały ponieść straty przekraczające $70 \mathrm{mln}$ zł. Oskarżonych sądzono w trybie doraźnym przed Sądem Apelacyjnym w Olsztynie. Wyrokiem z 6 października 1949 r. Jan Koziełł-Poklewski został skazany na karę śmierci, Stefan Kossakowski na karę 15 lat więzienia, Jerzy Binzer na 3 lata więzienia. 19 listopada 1949 r. Bierut skorzystał z prawa łaski i zasądzoną Poklewskiemu karę śmierci zamienił na karę dożywotniego więzienia. O nieprawidłowościach popełnionych przez skład orzekający świadczy fakt, że 14 lu-

${ }^{94}$ AAN, ZC PNZ, 429/1642, k. nlb., Zarząd Okręgowy PNZ w Łuczanach. Powierzchnia gospodarstw i użytkowanie gruntów, Tablica IIa, 19 IV 1946 r.; ibidem, k. nlb.; Zarząd Okręgowy PNZ w Olsztynie. Powierzchnia gospodarstw i użytkowanie gruntów, Tablica IIa, 16 IV 1946 r.; ibidem, k. nlb., Zatrudnienie w gospodarstwach objętych zespołami ZO PNZ w Łuczanach, Tablica IV a, 19 IV 1946 r.; ibidem, k. nlb., Zatrudnienie w gospodarstwach objętych zespołami ZO PNZ w Olsztynie, Tablica IV (obliczenia własne). 
tego 1950 r. Sąd Najwyższy w rozprawie rewizyjnej w sprawie J. Binzera uchylił wyrok z 6 października 1949 r. w części dotyczącej Binzera i uniewinnił go. 29 stycznia 1954 r. Sąd Najwyższy w rewizji nadzwyczajnej w sprawie Stefana Kossakowskiego zmienił pierwotnie zasądzony wyrok 15 lat więzienia i skazał go na 6 lat więzienia, orzeczoną karę złagodził do 4 lat i uznał wymierzoną karę za odbyta. Kolejne ustawy amnestyjne z 22 listopada 1952 r. i 27 kwietnia 1956 r. doprowadziły do złagodzenia wyroku J. Poklewskiego do 12 lat więzienia, a 20 kwietnia 1957 r., na skutek rewizji nadzwyczajnej, Sąd Najwyższy, dopatrując się poważnych uchybień byłego Sądu Apelacyjnego w Olsztynie, uchylił wyrok z 6 października 1949 r. w części dotyczącej J. Poklewskiego (pierwotnie skazujący go na karę śmierci). Obok powyższej sprawy Poklewskiemu w 1949 r. postawiono odrębny zarzut współpracy z Niemcami w czasie okupacji i przeprowadzono oddzielną rozprawę, w wyniku której 16 września 1949 r. skazano go na karę 15 lat więzienia. Wyrok ten w wyniku kolejnych amnestii również złagodzono: w 1953 r. do 10 lat, w 1956 r. do 5 lat, a w 1957 r. Sąd Wojewódzki postępowanie úmorzył, ponieważ, jak zapisano w postanowieniu, z powödū amnestii „należałoby orzec karę, która ulegałaby darowaniu" 95.

\section{Bibliografia}

Źródła archiwalne

AAN - Archiwum Akt Nowych

Komitet Centralny Polskiej Partii Robotniczej, sygn. 295/I-25, k. 36; sygn. 295/XII-7, k. 50; sygn. 295/XII-6, k. 139; sygn. 295/XII-61, k. 31, 68.

Zarząd Centralny Państwowych Nieruchomości Ziemskich, sygn. 429/1642, k. nlb.

Ministerstwo Rolnictwa i Reform Rolnych, sygn. 162/99, k. 6, 8-10.

AIPN Bi - Archiwum Instytutu Pamięci Narodowej Oddział w Białymstoku Raport dekadowy za okres 21-31 III 1946 r., sygn. 084/2, k. 22.

Sprawozdanie miesięczne szefa WUBP w Olsztynie za okres 1 X - 31 X 1945 r., sygn. 084/1, k. 60-61.

Sprawozdanie dekadowe Sekcji V WUBP w Olsztynie 19-29 IX 1945 r., sygn. 084/1, k. 25-26.

Sprawozdanie miesięczne za okres 1-29 XII 1945 r., sygn. 084/1, k. 174,

AIPN Ol - Archiwum Instytutu Pamięci Narodowej Delegatura w Olsztynie sygn.9/3-1; sygn. 9/3-2, sygn. 9/4.

APO - Archiwum Państwowe w Olsztynie

Komitet Wojewódzki Polskiej Partii Robotniczej, sygn. 1073/127, k. 71, 72, 79; sygn. 1073/127, k. 81; sygn. 1073/144, k. 32, 106; sygn. 1074/144, k. 174.

${ }^{95}$ Akta sądowe w wyżej wymienionych sprawach zob. Archiwum Instytutu Pamięci Narodowej Delegatura w Olsztynie, 9/3-1; AIPN Ol, 9/3-2, AIPN Ol, 9/4. 
Urząd Pełnomocnika Rządu RP na Okręg Mazurski, sygn. 390/65, k. 38-39; sygn. 390/241, k. 11. Wojewódzki Urząd Ziemski, sygn. 618/3, k. 154v-155; sygn. 618/4, k. 115, 151-152, 154-155, 157, 170, 171, 183, 186-187, 193, 194, 195; sygn. 618/8, k. 18-19, 43, 153; sygn. 618/12, k. 6, 45, 72-72v; sygn. 618/13, k. 45; sygn. 618/14, k. 23v, 26v, 28, 29, 30, 34; sygn. 618/15, k. 5, 185, 192 , 216; sygn. $618 / 18$, k. 23, 23v, 24v, 26v, 27v, 33, 34, 44, 44v, 46v, 48v, 49, 55v; sygn. 618/34, k. 31, 110, 167, 196.

Źródła drukowane

I Sesja Rady Naukowej dla Zagadnień Ziem Odzyskanych (30 VII - 1 VIII 1945 r.), Kraków 1945/1946, z. 1. II Sesja Rady Naukowej dla Zagadnień Ziem Odzyskanych (16-18 XII 1945 r.), Warszawa 1946, z. 2. Dziennik Ustaw 1944, Nr 2, poz. 4; Nr 4, poz. 17.

Okręg Mazurski w raportach Jakuba Prawina. Wybór dokumentów 1945 r. Przygotował do druku T. Baryła, Olsztyn 1996.

Układ zbiorowy pracy pomiędzy Państwowym Funduszem Ziemi a Związkiem Zawodowym Robotników i Pracowników Rolnych, Warszawa 5 czerwca 1945 r.

Warmiacy i Mazurzy w PRL. Wybór dokumentów. Rok 1945. Przygotował do druku T. Baryła, Olsztyn 1994.

Wspomnienia pracowników byłych Państwowych Gospodarstw Rolnych, opr. Z. Gładkowski, B. Pilarek, Olsztyn [2013].

\section{Opracowania}
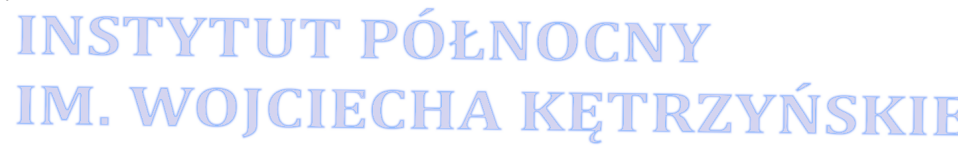

Belzyt L., Między Polska a Niemcami. Weryfikacja narodowościowa i jej następstwa na Warmii, Mazurach i Powiślu w latach 1945-1960, Toruń 1998.

Czołgoszewski J., Więziennictwo okresu stalinowskiego na Warmii i Mazurach w latach 1945-1956, Olsztyn 2002.

Gertner Z., Obóz Nakazowo-Rozdzielczy NKWD w Działdowie, Rocznik Działdowski, 1995, ss. 164-179.

Gieszczyński W., Państwowy Urząd Repatriacyjny w osadnictwie na Warmii i Mazurach (1945-1950), Olsztyn 1999.

Armia Sowiecka na Warmii i Mazurach w latach 1945-1948. Szkic do monografii, Zeszyty Naukowe Ostrołęckiego Towarzystwa Naukowego, 2013, nr 27, ss. 59-75.

Majątki ziemskie na Warmii i Mazurach pod sowiecka administracją wojskowa (1945-1948), w: Między historia polityczna a społeczna, red. J. Gołota, Pułtusk-Olsztyn-Ostrołęka-Warszawa 2014, ss. $287-303$.

Kersten K., U podstaw kształtowania się nowej struktury agrarnej ziem zachodnich (1945-1947), Polska Ludowa, 1962, t. 1, ss. 37-83.

Łukaszewicz B., Polskie Stronnictwo Ludowe na Warmii i Mazurach w latach 1945-1947, Olsztyn 1991.

Mucha J., Wilamowski B., Organizacja zarządzania oraz rozwój sił wytwórczych w gospodarstwach państwowych województwa olsztyńskiego w latach 1945-1961, Komunikaty Mazursko-Warmińskie, 1962, nr 1, ss. 226-270.

Pietrzak-Pawłowski K., Od Prus Wschodnich do województwa olsztyńskiego 1945-1947, Przegląd Zachodni, 1947, nr 2.

Skrzypek A., Mechanizmy uzależnienia. Stosunki polsko-radzieckie 1944-1957, Pułtusk 2002.

Wilamowski B., Studia założeń i początków osadnictwa rolnego na terenie woj. olsztyńskiego w latach 1945-1948, Olsztyn 1963 (maszynopis pracy doktorskiej), Biblioteka OBN. Zbiory specjalne.

Wpływ warunków naturalnych na wyniki ekonomiczne na przykładzie Państwowych Gospodarstw Rolnych województwa olsztyńskiego, Olsztyn 1966.

Podstawy analizy i oceny działalności gospodarstw państwowych na przykładzie woj. olsztyńskiego, Warszawa 1971. 
Zarys przemian polityczno-ekonomicznych regionu olsztyńskiego, Komunikaty Mazursko-Warmińskie, 1963, nr 3, s. 375-402.

Wilamowski B., Jaworowski J., Koncepcje w zakresie osadnictwa rolniczego $w$ województwie olsztyńskim w latach 1945-1948, Komunikaty Mazursko-Warmińskie, 1967, nr 3, ss. 321-360.

Wrzesiński W., Proces zasiedlania województwa olsztyńskiego w latach 1945-1949, w: Problemy rozwoju gospodarczego i demograficznego Ziem Zachodnich w latach 1945-1958, red. B. Gruchman, J. Ziółkowski, Poznań 1960, ss. 170-213.

Żyromski S., Procesy migracyjne w województwie olsztyńskim w latach 1945-1949, Olsztyn 1971.

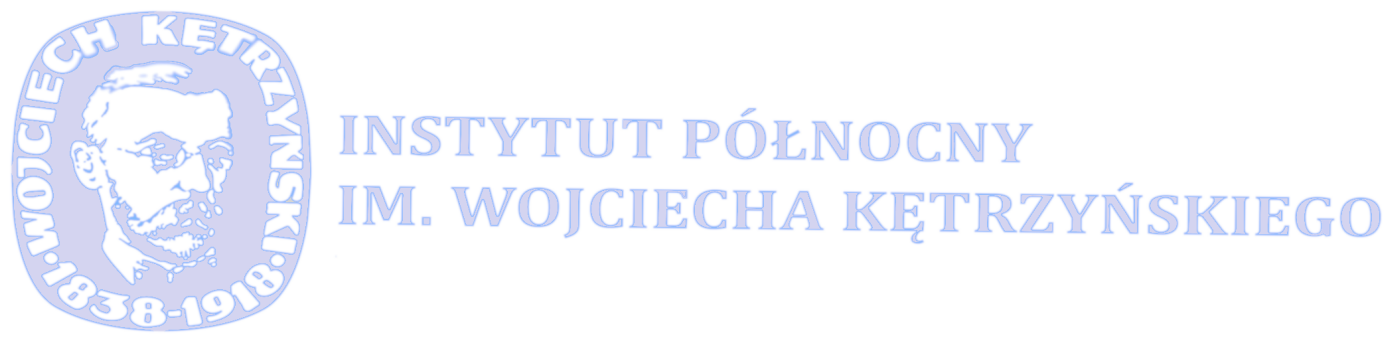

